\title{
Emissions of non-methane volatile organic compounds from combustion of domestic fuels in Delhi, India
}

\author{
Gareth J. Stewart $^{1}$, W. Joe F. Acton ${ }^{2, a}$, Beth S. Nelson ${ }^{1}$, Adam R. Vaughan ${ }^{1}$, James R. Hopkins ${ }^{1,3}$, Rahul Arya ${ }^{4,5}$, \\ Arnab Mondal ${ }^{4,5}$, Ritu Jangirh ${ }^{4,5}$, Sakshi Ahlawat ${ }^{4,5}$, Lokesh Yadav ${ }^{4,5}$, Sudhir K. Sharma ${ }^{4,5}$, Rachel E. Dunmore ${ }^{1}$, \\ Siti S. M. Yunus ${ }^{6}$, C. Nicholas Hewitt ${ }^{2}$, Eiko Nemitz $^{7}$, Neil Mullinger ${ }^{7}$, Ranu Gadi ${ }^{8}$, Lokesh K. Sahu ${ }^{9}$, Nidhi Tripathi ${ }^{9}$, \\ Andrew R. Rickard ${ }^{1,3}$, James D. Lee ${ }^{1,3}$, Tuhin K. Mandal ${ }^{4,5}$, and Jacqueline F. Hamilton ${ }^{1}$ \\ ${ }^{1}$ Wolfson Atmospheric Chemistry Laboratories, Department of Chemistry, University of York, York, YO10 5DD, UK \\ ${ }^{2}$ Lancaster Environment Centre, Lancaster University, Lancaster LA1 4YQ, UK \\ ${ }^{3}$ National Centre for Atmospheric Science, University of York, York, YO10 5DD, UK \\ ${ }^{4}$ CSIR-National Physical Laboratory, Dr. K.S. Krishnan Marg, New Delhi, Delhi 110012, India \\ ${ }^{5}$ Academy of Scientific \& Innovative Research, Ghaziabad, Uttar Pradesh 201 002, India \\ ${ }^{6}$ School of Water, Energy and Environment, Cranfield University, Cranfield, MK43 0AL, UK \\ ${ }^{7}$ UK Centre for Ecology and Hydrology, Bush Estate, Penicuik, EH26 0QB, UK \\ ${ }^{8}$ Indira Gandhi Delhi Technical University for Women, Kashmiri Gate, New Delhi, Delhi 110006, India \\ ${ }^{9}$ Physical Research Laboratory (PRL), Ahmedabad 380009, India \\ ${ }^{a}$ now at: School of Geography, Earth and Environmental Sciences, University of Birmingham, B15 2TT, Birmingham, UK
}

Correspondence: Jacqueline F. Hamilton (jacqui.hamilton@york.ac.uk)

Received: 26 August 2020 - Discussion started: 19 October 2020

Revised: 17 December 2020 - Accepted: 21 December 2020 - Published: 18 February 2021

\begin{abstract}
Twenty-nine different fuel types used in residential dwellings in northern India were collected from across Delhi (76 samples in total). Emission factors of a wide range of non-methane volatile organic compounds (NMVOCs) (192 compounds in total) were measured during controlled burning experiments using dualchannel gas chromatography with flame ionisation detection (DC-GC-FID), two-dimensional gas chromatography $(\mathrm{GC} \times \mathrm{GC}$-FID), proton-transfer-reaction time-of-flight mass spectrometry (PTR-ToF-MS) and solid-phase extraction two-dimensional gas chromatography with time-offlight mass spectrometry (SPE-GC $\times$ GC-ToF-MS). On average, $94 \%$ speciation of total measured NMVOC emissions was achieved across all fuel types. The largest contributors to emissions from most fuel types were small non-aromatic oxygenated species, phenolics and furanics. The emission factors (in $\mathrm{g} \mathrm{kg}^{-1}$ ) for total gas-phase NMVOCs were fuelwood (18.7, 4.3-96.7), cow dung cake (62.0, 35.3-83.0), crop residue $(37.9,8.9-73.8)$, charcoal $(5.4,2.4-7.9)$, sawdust $(72.4,28.6-115.5)$, municipal solid waste $(87.3$, 56.6$119.1)$ and liquefied petroleum gas $(5.7,1.9-9.8)$.
\end{abstract}

The emission factors measured in this study allow for better characterisation, evaluation and understanding of the air quality impacts of residential solid-fuel combustion in India.

\section{Introduction}

Biomass burning is the second largest source of trace gases to the troposphere, releasing around a half of global $\mathrm{CO}$, $\sim 20 \%$ of $\mathrm{NO}$ and $\sim 8 \%$ of $\mathrm{CO}_{2}$ emissions (Olivier et al., 2005; Wiedinmyer et al., 2011; Andreae, 2019). Biomass burning releases an estimated $62 \mathrm{Tg} \mathrm{yr}^{-1}$ of non-methane volatile organic compounds (NMVOCs) (Andreae, 2019) and is the dominant source of both black carbon (BC) and primary organic aerosol (POA), representing $59 \%$ and $85 \%$ of global emissions, respectively (Bond et al., 2013). Biomass burning includes open vegetation fires in forests, savannahs, agricultural burning and peatlands (Chen et al., 2017) as well as the biofuels used by approximately 3 billion people to meet their daily cooking and heating energy requirements worldwide (World Bank, 2020). A wide range 
of trace gases are released from biomass burning, in different amounts depending on the fuel type and the combustion conditions, meaning that detailed studies at the point of emission are required to accurately characterise emissions. The gases released lead to soil-nutrient redistribution (PonetteGonzalez et al., 2016; N'Dri et al., 2019); can themselves be toxic (Naeher et al., 2007); and can significantly degrade local, regional, and global air quality through the photochemical formation of secondary pollutants such as ozone $\left(\mathrm{O}_{3}\right)$ (Pfister et al., 2008; Jaffe and Wigder, 2012) and secondary organic aerosol (SOA) (Alvarado et al., 2015; Kroll and Seinfeld, 2008). They can also lead to indoor air quality issues (Fullerton et al., 2008).

Emissions from biomass burning and their spatial distribution remain uncertain, and estimates by satellite retrieval vary by over a factor of 3 (Andreae, 2019). Bottom-up approaches use information about emission factors and fuel usage. However, information for many developing countries, where solid fuels are a primary energy source, is particularly sparse. Toxic pollution from burning has been linked to chronic bronchitis (Akhtar et al., 2007; Moran-Mendoza et al., 2008), chronic obstructive pulmonary disease (Dennis et al., 1996; Orozco-Levi et al., 2006; Rinne et al., 2006; Ramirez-Venegas et al., 2006; Liu et al., 2007; Perez Padilla et al., 1996), lung cancer (Liu et al., 1993; Ko et al., 1997), childhood pneumonia (Smith et al., 2011), acute lower respiratory infections (Bautista et al., 2009; Mishra, 2003) and low birth weight of children (Boy et al., 2002; Yucra et al., 2011). Smoke from inefficient combustion of domestic solid fuels is the leading cause of conjunctivitis in developing countries (West et al., 2013). The harmful emissions from burning also resulted in an estimated 2.8-3.9 million premature deaths due to household air pollution (Kodros et al., 2018; WHO, 2018; Smith et al., 2014), of which $27 \%$ originated from pneumonia, $18 \%$ from strokes, $27 \%$ from ischaemic heart disease, $20 \%$ from chronic obstructive pulmonary disease and $8 \%$ from lung cancer, with hazardous indoor air pollution responsible for $45 \%$ of pneumonia deaths in children less than 5 years old (WHO, 2018). For this reason, hazardous indoor air pollution from the combustion of solid fuels has been calculated to be the most important risk factor for the burden of disease in South Asia from a range of 67 environmental and lifestyle risks (Lim et al., 2012; Smith et al., 2014).

The emissions from biomass burning fires are complex and can contain many hundreds to thousands of chemical species (Crutzen et al., 1979; McDonald et al., 2000; Hays et al., 2002; Hatch et al., 2018; Stewart et al., 2021c). Measurements of emissions by gas chromatography (GC) have been made (EPA, 2000; Wang et al., 2014; Gilman et al., 2015; Stockwell et al., 2016; Fleming et al., 2018), as it has the potential to provide isomeric speciation of emissions. However, it is of limited use in untargeted measurements from burning due to the complexity of emissions, leading to large amounts of NMVOCs released not being observed. Some of the main issues are that GC does not provide high time resolution measurements, and several instruments with different column configurations and detectors are required to provide information on different chemical classes. Samples can also be collected into canisters or sample bags and then analysed offline (Wang et al., 2014; Sirithian et al., 2018; Barabad et al., 2018), which can increase time resolution but can also lead to artefacts (Lerner et al., 2017).

Recent developments have allowed for the application of proton-transfer-reaction mass spectrometry (PTR-MS) to study the emissions from biomass burning (Warneke et al., 2011; Yokelson et al., 2013; Brilli et al., 2014; Stockwell et al., 2015; Bruns et al., 2016; Koss et al., 2018). PTR-MS uses proton transfer from the hydronium ion $\left(\mathrm{H}_{3} \mathrm{O}^{+}\right)$to ionise and simultaneously detect most polar and unsaturated NMVOCs including aromatics, oxygenated aromatics, alkenes, furanics and nitrogen-containing volatile organic compounds in gas samples. PTR-MS can measure at fast acquisition rates of up to $10 \mathrm{~Hz}$ over a mass range of $10-500 \mathrm{Th}$ (thomson) with very low detection limits of tens to hundreds of parts per trillion by volume (pptv) (Yuan et al., 2016). The more recently developed technique of proton-transfer-reaction timeof-flight mass spectrometry (PTR-ToF-MS) has allowed for around $90 \%$ of total measured NMVOC emissions in terms of mixing ratio from burning experiments to be speciated (Koss et al., 2018) and has also been used to study the formation of SOA (Bruns et al., 2016). The main disadvantages of the PTR-ToF-MS technique are its inability to speciate isomers, significant fragmentation of parent ions, only being able to detect species with a proton affinity greater than water and the formation of water clusters needing to be considered (Stockwell et al., 2015; Yuan et al., 2017). More recently, measurements have also been made using iodide chemical ionisation time-of-flight mass spectrometry ( ${ }^{-}$-CIMS), which is well suited to measuring acids and multifunctional oxygenates (Lee et al., 2014) as well as isocyanates, amides and organo-nitrate species released from biomass burning (Priestley et al., 2018). Multiple measurement techniques used in concert are therefore complementary, with the use of PTR-ToF-MS and simultaneous gas chromatography often alleviating some of the difficulties highlighted above.

Since the start of the century, rapid growth has resulted in India becoming the second largest contributor to NMVOC emissions in Asia (Kurokawa et al., 2013; Kurokawa and Ohara, 2020). However, effective understanding of the relative strength of different sources and subsequent mitigation has been limited by a deficiency of suitably detailed, spatially disaggregated emission inventories (Garaga et al., 2018). A current receptor-model study has shown elevated NMVOC concentrations at an urban site in Delhi to be predominantly due to vehicular emissions, with a smaller contribution from solid-fuel combustion (Stewart et al., 2021a). However, approximately $60 \%$ of total NMVOC emissions from India in 2010 were estimated to be due to solid-fuel combustion (Sharma et al., 2015). Other studies have also suggested that 
burning may lead to enhanced concentrations of pollutants such as polycyclic aromatic hydrocarbons in Delhi (Elzein et al., 2020). A need has therefore been identified to measure local source profiles to allow for evaluation with activity data to better understand the impact of unaccounted and unregulated local sources (Pant and Harrison, 2012).

Approximately $25 \%$ of worldwide residential solid-fuel use takes place in India (World Bank, 2020), with approximately $25 \%$ of ambient particulate matter in South Asia attributed to cooking emissions (Chafe et al., 2014). Despite large government schemes, traditional solid-fuel cookstoves remain popular in India; this is because they are cheaper than ones that use liquefied petroleum gas (LPG), and the meals cooked on them are perceived to be tastier (Mukhopadhyay et al., 2012). The total number of biofuel users has been sustained by an increasing population, despite the percentage use of biofuels decreasing as a proportion of overall fuel use due to increased LPG uptake (Pandey et al., 2014). Cow dung cakes remain prevalent as a fuel, because they are cheap, readily available, sustainable and ease pressure on local fuelwood resources. Few studies have reported emissions data from cow dung cake (Venkataraman et al., 2010; Stockwell et al., 2016; Koss et al., 2018; Fleming et al., 2018), leaving considerable uncertainty over the impact that cow dung cake combustion has on air quality. LPG usage has increased to 500 million users but only reflects around $10 \%$ of current rural fuel consumption (Gould and Urpelainen, 2018).

India-specific inventories which include residential burning indicate a considerable emission source of total NMVOCs of around 6000-7000 kt yr-1 (Pandey et al., 2014; Sharma et al., 2015). Burning is likely to have a large impact on air quality in India, but considerable uncertainties exist over the total amount of NMVOCs released, owing to a lack of India-specific emission factors and information related to the spatial distribution of emissions.

Few studies measuring highly speciated NMVOC emission factors from fuels specific to India exist. Recent studies using PTR-ToF-MS to develop emission factors, which are more reflective of the range of species emitted from burning, have focussed largely on grasses, crop residues and peat (Stockwell et al., 2015) as well as fuels characteristic of the western US (Koss et al., 2018). A previous study measured emission factors of NMVOCs from cow dung cake using gas chromatography with flame ionisation detection (GC-FID) of $8-32 \mathrm{~g} \mathrm{~kg}^{-1}$ (EPA, 2000). Fleming et al. (2018) quantified 76 NMVOCs from fuelwood and cow dung cake combustion using chulha and angithi stoves by collecting samples into Kynar bags; transferring their contents into canisters; and offline analysing samples using GC-FID, GC-ECD (electron capture detector), and GC-MS. The emission factors measured from these 76 NMVOCs were $14 \mathrm{~g} \mathrm{~kg}^{-1}$ for cow dung cake burnt in chulha stoves, $27 \mathrm{~g} \mathrm{~kg}^{-1}$ for cow dung cake burnt in angithi stoves and $6 \mathrm{~g} \mathrm{~kg}^{-1}$ for fuelwood burnt in angithi stoves. An emission factor from one single dung burn measured using PTR-ToF-MS was considerably larger at around $66 \mathrm{~g} \mathrm{~kg}^{-1}$ (Koss et al., 2018). Emissions from dung in Nepal have also been measured (Stockwell et al., 2016) by sampling into whole air sample canisters followed by offline analysis with GC-FID/ECD/MS and Fourier transform infrared spectroscopy (FTIR). However, very few speciated NMVOC measurements were made, and the emission factors were similar to those measured using just GC (Fleming et al., 2018). Studies have also focussed on making detailed measurements, using a range of techniques, from the burning of municipal solid waste (Christian et al., 2010; Yokelson et al., 2011, 2013; Stockwell et al., 2015, 2016; Sharma et al., 2019) and crop residues (Stockwell et al., 2015; Koss et al., 2018; Kumar et al., 2018).

Detailed chemical characterisation of NMVOC emissions from fuel types widely used in the developing world is much needed to resolve uncertainties in emission inventories used in regional policy models and global chemical transport models. A greater understanding of the key sources is required to characterise and hence understand air quality issues to allow for the development of effective mitigation strategies. In the present study, we measure comprehensive emission factors of NMVOCs from a range of solid fuels characteristic to northern India.

\section{Methods}

\subsection{Fuel collection and burning facility}

A total of 76 fuels, reflecting the range of fuel types used in northern India, were collected from across Delhi (see Fig. 1 and Table 1). Cow dung cake usage was prominent in the north and west regions, whereas fuelwood use was more evenly spread across the state. Municipal solid waste was collected from Bhalaswa, Ghazipur and Okhla landfill sites. Collection also included less used local fuel types which were found being burnt, including crop residues, sawdust and charcoal. A low-cost LPG stove, widely promoted across India as a cleaner fuel through government initiatives such as the Pradhan Mantri Ujjwala Yojana and Pratyaksh Hanstantrit Labh schemes, was used for direct emission comparison with other local fuel types.

Fuels were burnt at the CSIR-National Physical Laboratory (NPL), New Delhi, under controlled conditions utilising a combustion chamber based on the design of Venkataraman and Rao (2001). Several previous studies have been based on this chamber design (Venkataraman and Rao, 2001; Venkataraman et al., 2002; Saud et al., 2011, 2012; Singh et al., 2013), which was designed to simulate the convectiondriven conditions of real-world combustion and is displayed in Sect. S1 in the Supplement. The burn cycle used in this study was adapted from the Volunteers in Technical Assistance (VITA) water-boiling test, which was designed to simulate emissions from cooking and included emissions from both low- and high-temperature burning conditions. Fuels 
Table 1. Types and numbers of fuel samples burnt, the mean emission factor of total measured NMVOCs (TVOC) in $\mathrm{g} \mathrm{kg}^{-1}$ and standard deviation (SD) from all available burns.

\begin{tabular}{lrrr|lrrr}
\hline Fuelwood types & $n$ & TVOC & SD & Other & $n$ & TVOC & SD \\
\hline Azadirachta indica & 3 & 18.6 & 7.9 & Cow dung cake & 8 & 61.9 & 18.4 \\
Morus spp. & 4 & 27.4 & 21.1 & Cocos nucifera & 2 & 57.4 & 23.3 \\
Melia azedarach & 2 & 23.7 & 13.1 & Charcoal & 2 & 5.1 & 3.9 \\
Shorea spp. & 2 & 9.8 & 2.2 & Sawdust & 2 & 71.3 & 60.8 \\
Ficus religiosa & 2 & 51.9 & 63.4 & Waste & 3 & 87.3 & 31.4 \\
Syzygium spp. & 2 & 8.9 & 4.9 & LPG & 3 & 5.8 & 5.6 \\
Ficus spp. & 2 & 7.1 & 1.2 & Cow dung cake mix & 1 & 34.7 & - \\
Vachellia spp. & 2 & 13.5 & 9.7 & Solanum melongena & 2 & 13.6 & 6.5 \\
Dalbergia sissoo & 2 & 17.9 & 8.8 & Brassica spp. & 2 & 41.0 & 45.5 \\
Ricinus spp. & 2 & 8.5 & 2.5 & & & & \\
Holoptelea spp. & 2 & 6.0 & 0.8 & & & & \\
Mixed woods & 1 & 6.1 & - & & & & \\
Saraca indica & 2 & 12.9 & 5.2 & & & & \\
Populus spp. & 1 & 8.5 & - & & & & \\
Pithecellobium spp. & 2 & 19.5 & 5.4 & & & & \\
Eucalyptus spp. & 2 & 6.9 & 1.9 & & & & \\
Prosopis spp. & 6 & 14.5 & 10.4 & & & & \\
Mangifera indica & 2 & 12.4 & 3.4 & & & & \\
Plywood & 8 & 26.6 & 24.3 & & & & \\
Processed wood & 2 & 33.7 & 17.2 & & & & \\
\hline
\end{tabular}

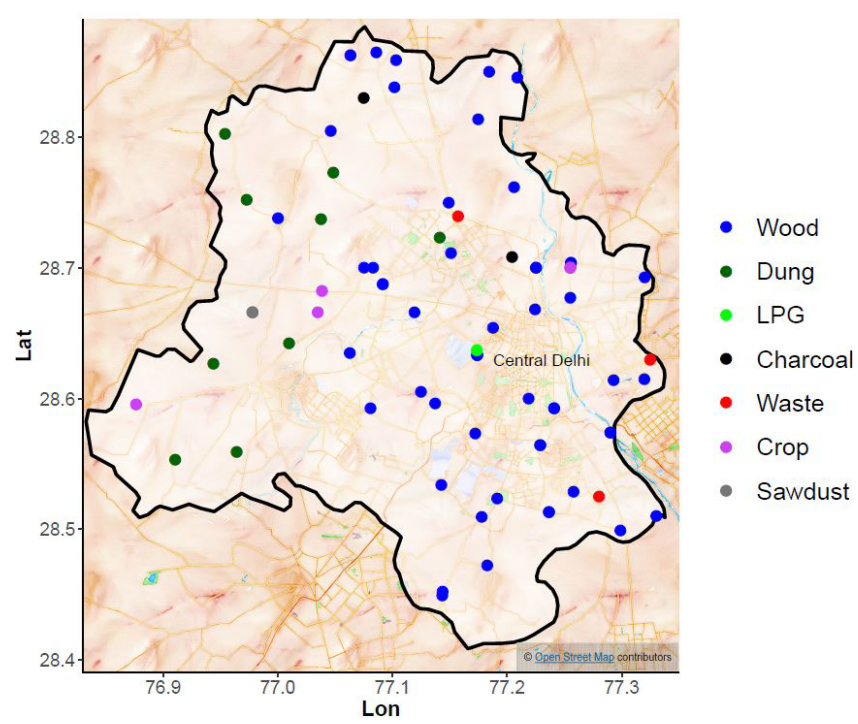

Figure 1. Locations across Delhi used for the local surveys of fuel use and collection of representative biomass fuels. Map tiles by Stamen Design. Data by (C) OpenStreetMap contributors 2020. Distributed under a Creative Commons BY-SA License.

were collected and stored in the same manner as local customs using expert local judgement. This method was designed to ensure that the moisture content of fuelwood samples was like those being burnt locally and that the combustion replicated real-world burning conditions encountered in local cooking practices, which should consequently give a more reflective NMVOC emission factor.

Fuel $(200 \mathrm{~g})$ was placed $45 \mathrm{~cm}$ from the top of the hood and rapidly heated to spontaneous ignition, with emissions convectively driven into a hood and up a flue to allow enough dilution, cooling and residence time to achieve the quenching typically observed in indoor environments. These conditions have been previously optimised to ensure that emissions entrainment into the hood did not exert a draught which altered combustion conditions. The mid-point velocity of gases driven up the flue by convection was measured by a platinum hot-wire sensor, calibrated for total flow rate using a standard orifice calibrator. Samples were drawn down a sample line at 4. $4 \mathrm{~L} \mathrm{~min}^{-1}$ (Swagelok, 1/4 in. PFA, $<2.2 \mathrm{~s}$ residence time) from the top of the flue, passed through a pre-conditioned quartz filter $\left(\varnothing=47 \mathrm{~mm}\right.$, conditioned at $550^{\circ} \mathrm{C}$ for $6 \mathrm{~h}$ and changed between samples) and held in a filter holder (ColeParmer, PFA) which was subsampled for analysis by PTRToF-MS, GC $\times$ GC-FID and DC-GC-FID instruments at a distance no greater than $5 \mathrm{~m}$ from the top of the flue.

Measurements of $n$-alkanes from $n$-tridecane $\left(\mathrm{C}_{13}\right)$ to eicosane $\left(\mathrm{C}_{20}\right)$ were also made from a subset of 29 burns using solid-phase extraction discs (SPE, Resprep, $\mathrm{C}_{18}$ ). Samples were passed through a cooling and dilution chamber designed to replicate the immediate condensational processes that occur in smoke particles approximately 5-20 min after emission yet prior to photochemistry which may change composition (Akagi et al., 2011). Further details of the SPE sample collection are given in Stewart et al. (2021c). 


\subsection{PTR-ToF-MS}

The PTR-ToF-MS (PTR 8000; Ionicon Analytik, Innsbruck) instrument from the Physical Research Laboratory (PRL), Ahmedabad, was used to quantify 107 masses and subsampled the common inlet line using 1/4 in. PFA (perfluoroalkoxy alkane). Additional details of the PTR-ToF-MS system used in this study are given in previous papers (Sahu and Saxena, 2015; Sahu et al., 2016). The sample air was diluted into zero air, generated by passing ambient air $\left(1 \mathrm{~L} \mathrm{~min}^{-1}\right)$ through a heated platinum filament at $550^{\circ} \mathrm{C}$ before entering the instrument with an inlet flow of $250 \mathrm{~mL} \mathrm{~min}^{-1}$. Samples were diluted by either 5 or 6.25 times $\left(50 \mathrm{~mL} \mathrm{~min}^{-1}\right.$ in $200 \mathrm{~mL} \mathrm{~min}^{-1}$ zero air or $40 \mathrm{~mL} \mathrm{~min}^{-1}$ in $210 \mathrm{~mL} \mathrm{~min}^{-1}$ zero air). The instrument was operated with an electric field strength $(E / N$, where $N$ is the buffer gas density and $E$ is the electric field strength) of $120 \mathrm{Td}$ (townsend, $1 \mathrm{Td}=10$ $17 \mathrm{~V} \mathrm{~cm}^{2}$ ). The drift tube temperature was $60^{\circ} \mathrm{C}$ with a pressure of $2.3 \mathrm{mbar}$ and $560 \mathrm{~V}$ applied across it.

Calibrations were performed twice a week using a gas calibration unit (Ionicon Analytik, Innsbruck). The calibration gas (Apel-Riemer Environmental Inc., Miami) contained 18 compounds: methanol, acetonitrile, acetaldehyde, acetone, dimethyl sulfide, isoprene, methacrolein, methyl vinyl ketone, 2-butanol, benzene, toluene, 2-hexanone, $m$-xylene, heptanal, $\alpha$-pinene, 3-octanone and 3-octanol at $1000 \mathrm{ppbv}$ $( \pm 5 \%)$, and $\beta$-caryophyllene at $500 \mathrm{ppbv}( \pm 5 \%)$. This standard was dynamically diluted into zero air to provide a sixpoint calibration. The normalized counts per second (ncps) per ppbv of the NMVOC (ncps/ppbv) was then determined for each mass using a transmission curve (Taipale et al., 2008). The maximum error in this calibration approach was shown to be $21 \%$ (Taipale et al., 2008). Peak assignment was assisted with results reported by previous burning studies and references therein (Brilli et al., 2014; Stockwell et al., 2015; Koss et al., 2018). The results may also contain other indistinguishable structural isomers not mentioned here.

Mass calibration and peak fitting of PTR-ToF-MS data were performed using PTRwid software (Holzinger, 2015). Count rates per second (cps) of each mass spectral peak were normalised to the primary ion $\left(\mathrm{H}_{3} \mathrm{O}^{+}\right)$and water cluster $\left(\mathrm{H}_{3} \mathrm{O} \cdot \mathrm{H}_{2} \mathrm{O}\right)^{+}$peaks, and mixing ratios were then determined for each mass using the normalised sensitivity. Where compounds known to fragment in the PTR-ToF-MS were identified, the mixing ratio of these species was calculated by summing parent ion and fragment ion mixing ratios. Before each burn, ambient air was sampled to provide a background for the measurement.

Petrol and diesel fuel samples were collected from an Indian Oil fuel station in Pusa, New Delhi, and the headspace was analysed to allow for comparison of benzene-to-toluene ratios. This method was designed to analyse the ratios in evaporative emissions, as these have been shown to be an important source of atmospheric NMVOCs (Srivastava et al., 2005; Rubin et al., 2006; Yamada et al., 2015), which for example represented $\sim 15 \%$ of anthropogenic UK NMVOC emissions in 2018 (Lewis et al., 2020). Fuel samples were placed in a small metal container (1/4 in. Swagelok cap) which was connected to a two-way tap (1/4 in. Swagelok). The tap was connected to a T-piece (1/4 in. Swagelok), which had a flow of zero air $\left(250 \mathrm{~mL} \mathrm{~min}^{-1}\right)$ passed through it and could be sampled by the PTR-ToF-MS. The tap was then opened to analyse the headspace of fuels.

\subsection{DC-GC-FID}

Gas chromatography was used to analyse entire burns to provide an integrated picture of emissions from fuel types. The DC-GC-FID sampled 51 burns to measure $19 \mathrm{C}_{2}-\mathrm{C}_{7}$ nonmethane hydrocarbons (NMHCs) and $\mathrm{C}_{2}-\mathrm{C}_{5}$ oxygenated NMVOCs (OVOCs) (Hopkins et al., 2003). A $500 \mathrm{~mL}$ sample $\left(1.5 \mathrm{~L}\right.$ pre-purge of $100 \mathrm{~mL} \mathrm{~min}^{-1}$ for $15 \mathrm{~min}$, sample at $17 \mathrm{~mL} \mathrm{~min}^{-1}$ for $30 \mathrm{~min}$ ) was collected (Markes International CIA Advantage), passed through a glass finger at $-30^{\circ} \mathrm{C}$ to remove water and adsorbed onto a dualbed sorbent trap (Markes International ozone precursors trap) at $-20^{\circ} \mathrm{C}$ (Markes International Unity 2). The sample was thermally desorbed $\left(250^{\circ} \mathrm{C}\right.$ for $\left.3 \mathrm{~min}\right)$ then split 50:50 and injected into two separate columns for analysis of NMHCs $\left(50 \mathrm{~m} \times 0.53 \mathrm{~mm} \mathrm{Al} \mathrm{O}_{2}\right.$ PLOT $)$ and OVOCs $(10 \mathrm{~m} \times 0.53 \mathrm{~mm}$ LOWOX with $50 \mu \mathrm{m}$ restrictor to balance flow). The oven was held at $40^{\circ} \mathrm{C}$ for $5 \mathrm{~min}$, then heated at $13^{\circ} \mathrm{C} \mathrm{min}^{-1}$ to $110^{\circ} \mathrm{C}$, and then finally heated at $8^{\circ} \mathrm{C} \mathrm{min}^{-1}$ to $200^{\circ} \mathrm{C}$ with a $30 \mathrm{~min}$ hold.

\subsection{GC $\times$ GC-FID}

The $\mathrm{GC} \times \mathrm{GC}$-FID was used to measure $58 \mathrm{C}_{7}-\mathrm{C}_{12}$ hydrocarbons $\left(\mathrm{C}_{7}-\mathrm{C}_{12}\right.$ alkanes, monoterpenes and monoaromatics) and collected $3 \mathrm{~L}$ samples $\left(100 \mathrm{~mL} \mathrm{~min}^{-1}\right.$ for $\left.30 \mathrm{~min}\right)$ using an adsorption-thermal-desorption system (Markes International Unity 2). NMVOCs were trapped onto a sorbent (Markes International U-T15ATA-2S) at $-20^{\circ} \mathrm{C}$ with water removed in a glass cold finger at $-30^{\circ} \mathrm{C}$, removed and heated to $\sim 100^{\circ} \mathrm{C}$ after each sample to prevent carry-over of unanalysed, polar interfering compounds. The sample was thermally desorbed $\left(250^{\circ} \mathrm{C}\right.$ for $5 \mathrm{~min}$ ) and injected splitless down a transfer line. Analytes were refocussed for $60 \mathrm{~s}$ using liquid $\mathrm{CO}_{2}$ at the head of a non-polar BPX5 held at $50 \mathrm{psi}(1 \mathrm{psi}=6.9 \mathrm{kPa})$ (SGE Analytical, $15 \mathrm{~m} \times 0.15 \mu \mathrm{m} \times 0.25 \mathrm{~mm}$ ), which was connected to a polar BPX50 at 30psi (SGE Analytical, $2 \mathrm{~m} \times 0.25 \mu \mathrm{m} \times 0.25 \mathrm{~mm}$ ) via a modulator held at $180^{\circ} \mathrm{C}$ (5 s modulation, Analytical Flow Products ELDV2-MT). The oven was held for $2 \mathrm{~min}$ at $35^{\circ} \mathrm{C}$, then ramped at $2.5^{\circ} \mathrm{C} \mathrm{min}-1$ to $130^{\circ} \mathrm{C}$ and held for 1 min with a final ramp of $10^{\circ} \mathrm{C} \mathrm{min}^{-1}$ to $180^{\circ} \mathrm{C}$ and a hold of $8 \mathrm{~min}$. The GC systems were tested for breakthrough to ensure trapping of the most volatile components (see Sect. S2). Calibration was carried out using $4 \mathrm{ppbv}$ gas standards containing alkanes, 
alkenes and aromatics purchased from the British National Physical Laboratory and through the relative response of liquid standard injections to toluene for components not in this gas standard, as detailed elsewhere (Dunmore et al., 2015; Stewart et al., 2021a). Integration of peak areas was performed in Zoex GC image software (Zoex, USA). Peaks were individually checked, and where peaks were split in the software, they were manually joined. The areas corresponding to alkane isomers were manually joined within the GC image software and calibration performed by comparing the areas to the corresponding $n$-alkane. For both GC instruments, blanks of ambient air were made at the beginning, middle and end of the day, and the mean was subtracted from samples.

\subsection{GC x GC-ToF-MS}

Measurements of a subset of 29 burns of $\mathrm{C}_{13}-\mathrm{C}_{20}$ alkanes were made, as well as other gas-phase species to assist with qualification of masses measured by PTR-ToF-MS, by adsorbing samples to the surface of SPE discs with analysis by GC $\times$ GC-ToF-MS, as detailed in Stewart et al. (2021c). Samples of $180 \mathrm{~L}$ were adsorbed to the surface of $\mathrm{C}_{18}$ coated SPE discs (Resprep, $\mathrm{C}_{18}, 47 \mathrm{~mm}$ ) prewashed with $2 \times 5 \mathrm{~mL}$ acetone washes and $1 \times 5 \mathrm{~mL}$ methanol wash. These samples were collected at $6 \mathrm{~L} \mathrm{~min}^{-1}$ over $30 \mathrm{~min}$ using a lowvolume sampler (Vayubodhan Pvt. Ltd), which passed samples through a cooling and dilution chamber at $46.7 \mathrm{~L} \mathrm{~min}^{-1}$. Samples were then wrapped in foil, placed in an airtight bag and kept frozen until analysis.

SPE extracts were spiked with an internal standard (EPA 8270 Semivolatile Internal Standard Mix, $2000 \mu \mathrm{g} \mathrm{mL}^{-1}$ in DCM, dichloromethane) and extracted using accelerated solvent extraction into ethyl acetate. Extracts were analysed using GC $\times$ GC-ToF-MS (Leco Pegasus BT 4D) using a 10:1 split injection $(1 \mu \mathrm{L}$ injection, $4 \mathrm{~mm}$ taper focus liner, SHG 560302). The primary dimension column was a RXI-5SilMS (Restek, $30 \mathrm{~m} \times 0.25 \mu \mathrm{m} \times 0.25 \mathrm{~mm}$ ) connected to a second column of RXI-17SilMS (Restek, $0.25 \mu \mathrm{m} \times 0.25 \mathrm{~mm}, 0.17 \mathrm{~m}$ primary GC oven, $0.1 \mathrm{~m}$ modulator, $1.42 \mathrm{~m}$ secondary oven, $0.31 \mathrm{~m}$ transfer line) under a He flow of $1.4 \mathrm{~mL} \mathrm{~min}^{-1}$. The primary oven was held at $40^{\circ} \mathrm{C}$ for $1 \mathrm{~min}$ and then ramped at $3{ }^{\circ} \mathrm{C} \mathrm{min}^{-1}$ to $202^{\circ} \mathrm{C}$ where it was held for $0.07 \mathrm{~min}$. The secondary oven was held at $62^{\circ} \mathrm{C}$ for $1 \mathrm{~min}$ and then ramped at $3.2^{\circ} \mathrm{C} \mathrm{min}^{-1}$ to $235^{\circ} \mathrm{C}$. The inlet was held at $280^{\circ} \mathrm{C}$ and the transfer line at $340^{\circ} \mathrm{C}$. A $5 \mathrm{~s}$ cryogenic modulation was used with a $1.5 \mathrm{~s}$ hot pulse and $1 \mathrm{~s}$ cool time between stages.

Peak assignment was conducted through comparison of retention times to known standards and comparison to the National Institute of Standards and Technology (NIST) mass spectral library. Integration was carried out within the ChromaTOF 5.0 software package (Leco, 2019). Eight blank measurements were made at the beginning and end of the day by passing air from the chamber $\left(6 \mathrm{~L} \mathrm{~min}^{-1}\right.$ for $\left.30 \mathrm{~min}\right)$ through the filter holder containing a PTFE filter and an SPE disc.
Blank corrections have been applied by subtracting the mean of blank values closest to measurement of the sample. An eight-point calibration was performed for $n$-alkanes using a commercial standard $\left(\mathrm{C}_{7}-\mathrm{C}_{40}\right.$ saturated alkane standard, certified $1000 \mu \mathrm{g} \mathrm{mL}^{-1}$ in hexane, Sigma-Aldrich 49452-U) diluted in the range $0.25-10 \mu \mathrm{gL}^{-1}$.

\section{Results}

\subsection{Comparison of chromatograms from combustion of different fuel types}

Figure 2 shows GC $\times$ GC-FID chromatograms obtained from collecting the emissions during the combustion of LPG (Fig. 2a), Saraca indica fuelwood (Fig. 2b), cow dung cake (Fig. 2c) and municipal solid waste (Fig. 2d). Figure $2 d$ is labelled to show the position of NMVOCs measured and displays a homologous series of $n$-alkanes from $n$-heptane $\left(\mathrm{C}_{7}\right)$ to $n$-tetradecane $\left(\mathrm{C}_{14}\right)$ along the bottom, with the 1alkenes positioned to the left. Above are more polar species such as monoterpenes, aromatics from benzene to substituted monoaromatics with up to five carbon substituents, and at a higher second dimension retention time even more polar species, such as styrene.

Many peaks were present in the chromatograms for cow dung cake and municipal solid waste, and these fuels released significantly more NMVOCs per unit mass than fuelwood and LPG (see Table 1). Cow dung cake and municipal solid waste released a range of NMVOCs including $n$-alkanes, alkenes and aromatics. The municipal solid waste (Fig. 2d) showed a particularly large and tailing peak numbered 22, owing to large emissions of styrene. Several unidentified peaks were observed in these complex samples which were broad in the second dimension. These were assumed to be from polar, oxygenated species formed during burning such as phenol. These species could not be identified and were not analysed using the GC $\times$ GC-FID instrument. Peaks have been omitted if these species were found to interfere significantly. Analysis has only been carried out using the DC-GC-FID from ethane $\left(\mathrm{C}_{2}\right)$ to $n$-hexane $\left(\mathrm{C}_{6}\right)$, owing to the significant presence of coeluting peaks. The large peak in the LPG chromatogram (Fig. 2, primary dimension retention time $\sim 6 \mathrm{~min}$, secondary dimension retention time $\sim 0.5 \mathrm{~s}$ ) was from unresolved propane and butane because of the high concentrations from this fuel source.

\subsection{PTR-ToF-MS concentration time series analysis}

Figure 3 shows an example concentration-time-series plot measured by the PTR-ToF-MS for a cow dung cake burn. A sharp rise in NMVOC emissions was seen from the start of the burn, which decreased as the fuel was combusted. Emissions of small oxygenated species as well as phenolics and furanics were dominant throughout most of the burn. At the beginning, a greater proportion of lower-mass species 

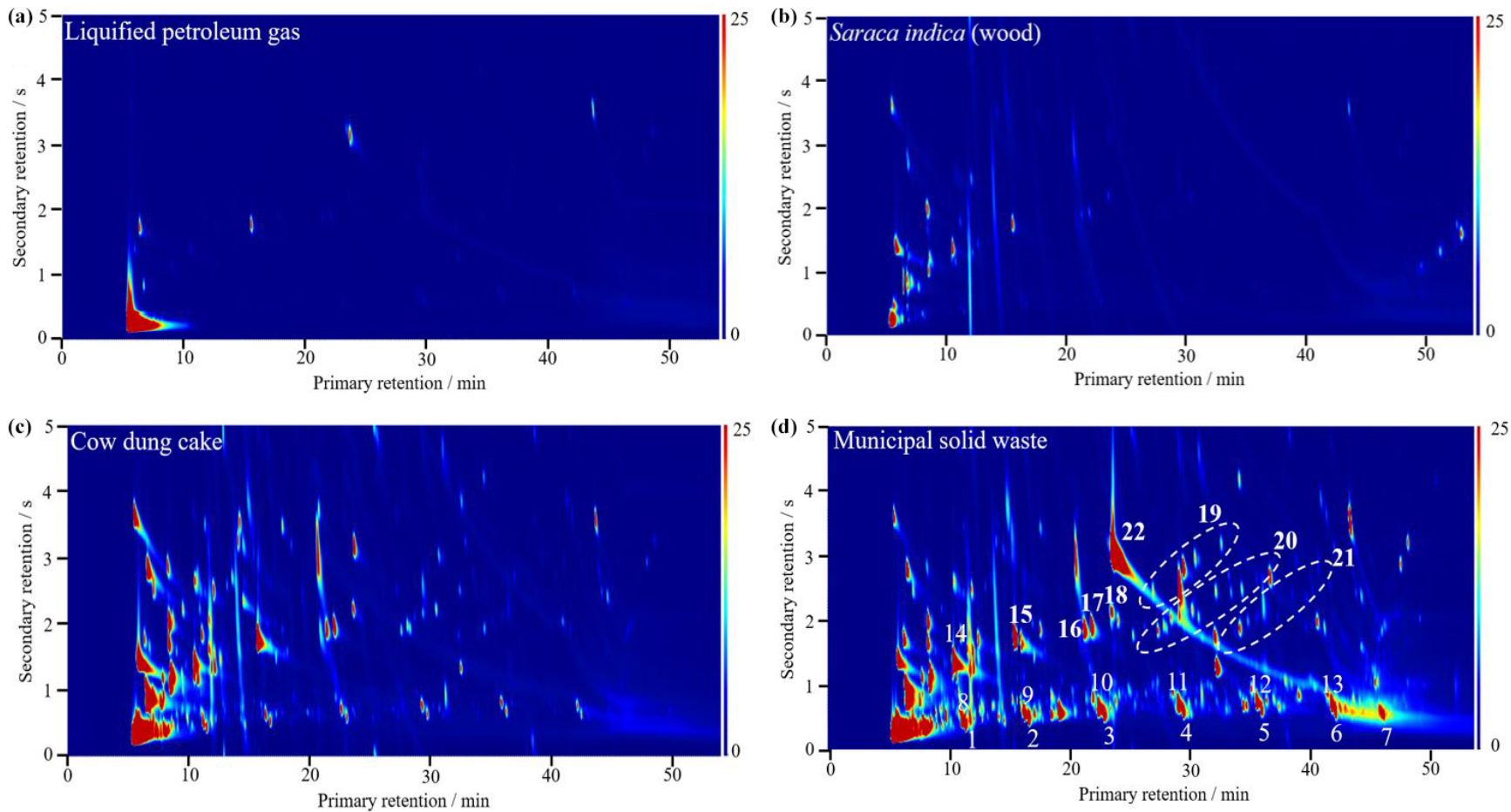

Figure 2. GC $\times$ GC-FID chromatograms from burning (a) LPG, (b) Saraca indica (fuelwood), (c) cow dung cake and (d) municipal solid waste samples where 1-7 $=n$-octane to $n$-tetradecane, $8-13=1$-octadecene to 1 -tridecene, $14=$ benzene, $15=$ toluene, $16=$ ethylbenzene, $17=m / p$-xylene, $18=o$-xylene, $19=\mathrm{C}_{3}$-substituted monoaromatics, $20=\mathrm{C}_{4}$-substituted monoaromatics and $21=\mathrm{C}_{5}$-substituted monoaromatics and $22=$ styrene. Samples (a)-(d) were collected with the same sample collection parameters, and the chromatograms are set at the same contrast level to allow for direct comparison between different fuel types.

were released, as shown in the binned mass spectrum of region A in Fig. 3. At the end in the smouldering phase, emissions were dominated by heavier and lower-volatility species (Fig. 3, region B). A previous study indicated highermolecular-weight phenolics were from low-temperature pyrolysis (Sekimoto et al., 2018).

Figure 4 shows the cumulative mass of species measured from burns of fuelwood, cow dung cake, municipal solid waste and charcoal as a proportion of the total mass of NMVOCs quantified using PTR-ToF-MS. The results were like those reported by Brilli et al. (2014) and Koss et al. (2018): $65 \%-90 \%$ of the mass of NMVOCs at emission originated from around 40 NMVOCs, with around $70 \%-90 \%$ identification by mass when quantifying around 100 NMVOCs. The largest contributors to the NMVOC mass from burning of fuelwood and cow dung cake were methanol $(\mathrm{m} / \mathrm{z}$ 33.034); acetic acid $(\mathrm{m} / \mathrm{z} 61.028)$; and a peak that reflected the sum of hydroxyacetone, methyl acetate, and ethyl formate $(m / z$ 75.043). For municipal solid waste samples, around $28 \%$ of total mass was from methyl methacrylate $(m / z 101.059)$ and styrene $(m / z 105.068)$, and two of the three municipal solid waste samples released significant quantities of styrene, most likely the result of degradation of polystyrene in the samples.
Figure 5 shows a concentration time series for phenolics and furanics from the burning of an example fuelwood. Most species of similar functionality tracked each other. Stockwell et al. (2015) demonstrated that benzene, phenol and furan could act as tracers for aromatic, phenolic and furanic species released from biomass burning. Figure 5a shows that heavier, more substituted phenolics appeared to be released at cooler temperatures. Guaiacol (dark blue) was released at the start of the flaming phase before the temperature increased and more phenol (red) was released at higher burn temperatures. Later in the burn, a larger proportion of vinyl guaiacol (pink) and syringol (yellow) were emitted. This agreed well with previous results which showed that species emitted from lower temperature depolymerisation had a larger proportion of low-volatility compounds compared to higher temperature processes during flaming (Sekimoto et al., 2018; Koss et al., 2018). Figure 5 b shows concentration time series of furanic species, with most species showing similar characteristics throughout the burn. The only species to peak later in the burn was 2-hydroxymethyl-2-furan. 

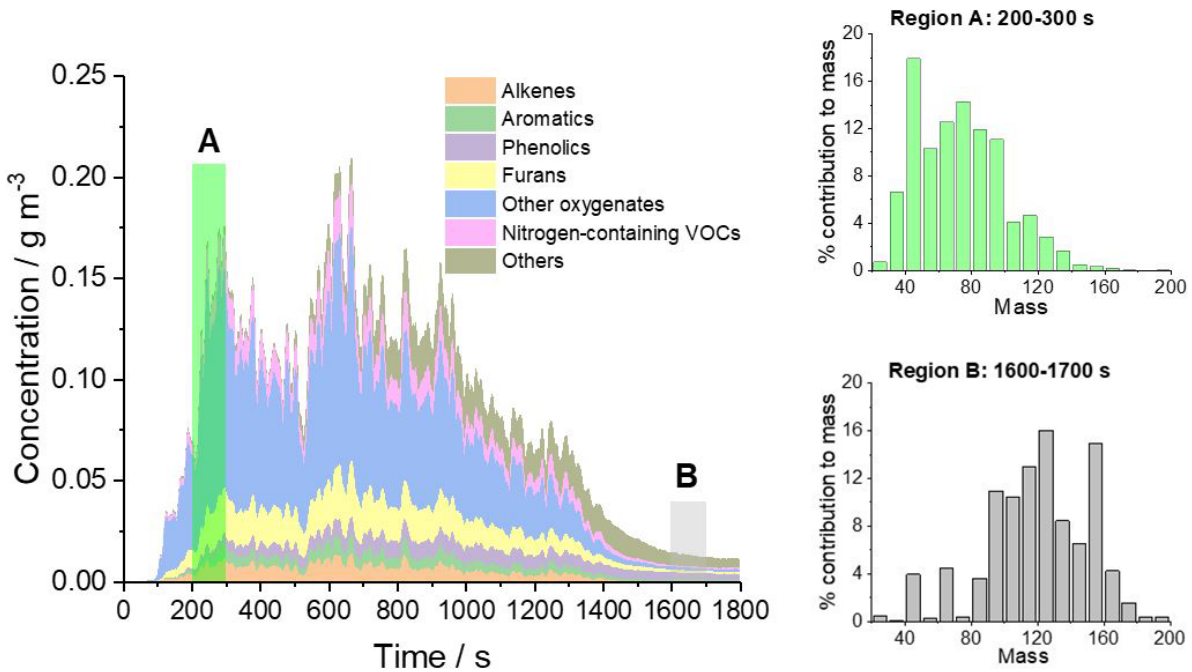

Figure 3. PTR-ToF-MS concentration-time-series plot during the first $30 \mathrm{~min}$ of a cow dung cake burn coloured by functionality with regions A and B displaying mass spectra placed into $\mathrm{m} / \mathrm{z}$ bins of $10 \mathrm{Th}$. Fuel was collected from Pitam Pura, Delhi.
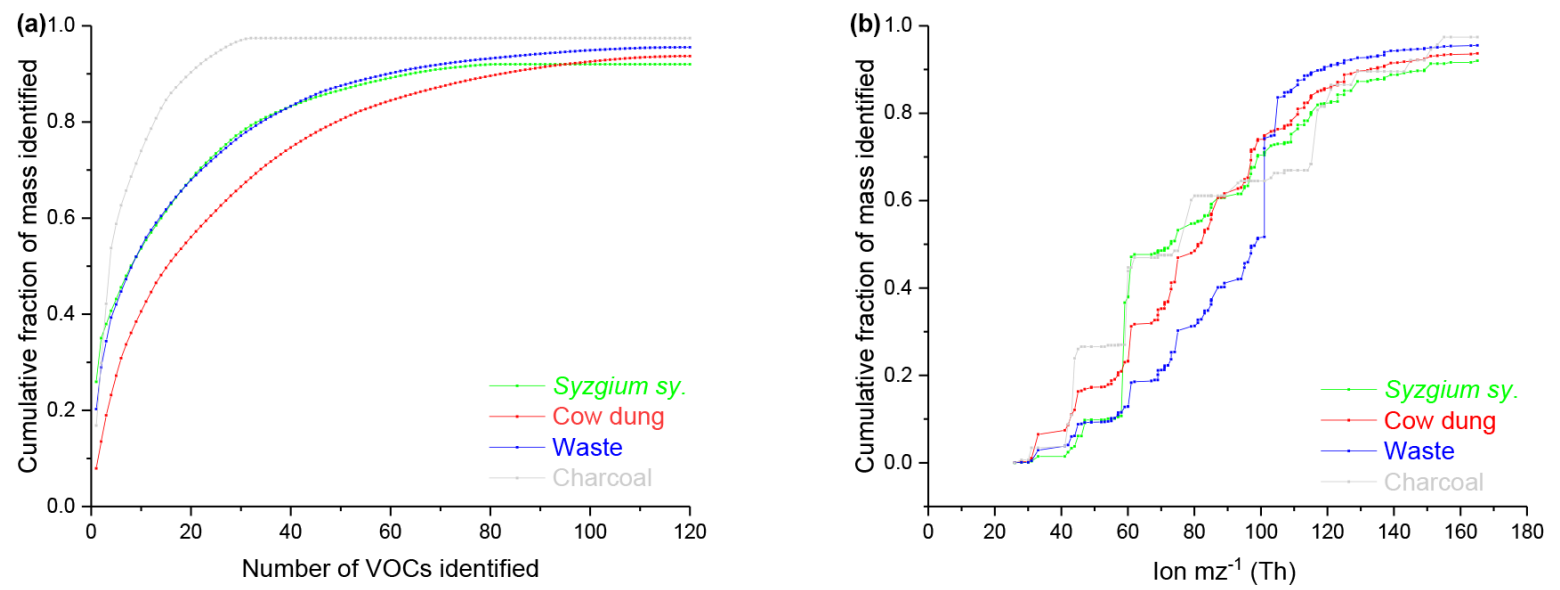

Figure 4. Cumulative NMVOC mass identified from PTR-ToF-MS compared with total NMVOC signal measured by PTR-ToF-MS with (a) ordered by decreasing NMVOC mass contribution and (b) ordered by ion mass. High quantification of emissions from charcoal was due to a low emission factor $\left(2.4 \mathrm{~g} \mathrm{~kg}^{-1}\right)$.

\subsection{Comparison of emissions data obtained with different instruments}

Previous instrument intercomparisons from biomass burning samples were between PTR-MS, GC-MS and openpath FTIR (Gilman et al., 2015) and between PTR-ToF-MS, FTIR, airborne cavity-enhanced spectroscopy (ACES) and $\mathrm{I}^{-}$-CIMS (Koss et al., 2018). Gilman et al. (2015) showed generally good agreement of slopes of measured emission factors between benzene, ethyne, furan, ethene, propene, methanol, toluene, isoprene and acetonitrile using different instruments and/or techniques with slopes of $\sim 1 \pm 0.3 \%$ and correlation coefficients $>0.9$. Koss et al. (2018) showed mean measured values of most NMVOCs from all burns with other instruments compared to the PTR-ToF-MS which agreed within a factor of 2 and had correlation coefficients $>0.8$ for most species except butadienes, furan, hydroxyacetone, furfural, phenol and glyoxal. These previous comparisons indicate the level of consistency expected with instrument comparisons of quantitative NMVOC measurements from burning experiments.

Figure 6 shows a comparison of measurements made using the DC-GC-FID, GC $\times$ GC-FID and PTR-ToF-MS techniques. Bar plots show that the mean and lower/upper quartiles of all measurements agreed within a factor of 2 . The correlation coefficient between different instruments is given by blue circles, with all $>0.8$. Generally, the mean values measured for the PTR-ToF-MS were slightly larger than using the GC instruments, which was attributed to the presence of other undistinguishable structural isomers measured 
(a)

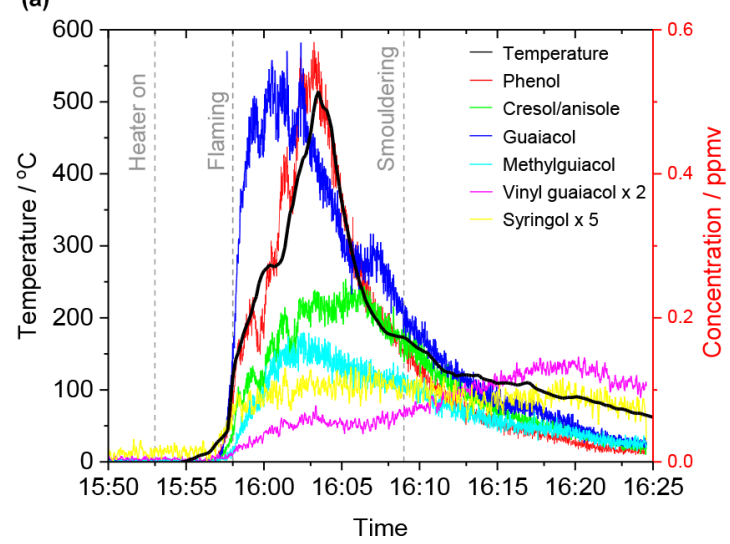

(b)

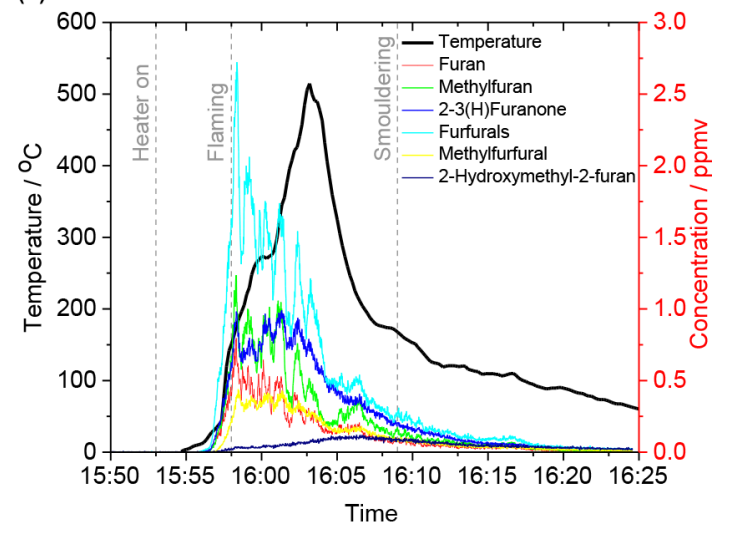

Figure 5. Concentration time series analysis of phenolic and furanic compounds released from burning of Azadirachta indica which released $27.0 \mathrm{~g} \mathrm{~kg}^{-1}$ of NMVOCs. Temperature corresponds to the increase in temperature above ambient measured in the flame directly above the combustion experiment.

by the PTR-ToF-MS. Comparison between DC-GC-FID and $\mathrm{GC} \times \mathrm{GC}$-FID measurements were also complicated by high levels of coelution of additional NMVOC species released from combustion with similar retention times $\left(R_{\mathrm{t}}\right)$ to benzene/toluene $\left(R_{\mathrm{t}}=21 / 25 \mathrm{~min}\right)$ on the DC-GC-FID instrument. Generally, the smallest values were measured with the GC $\times$ GC-FID instrument, consistent with the greatest ability to speciate isomers and limit the impacts of coelution. Significant efforts were made to synchronise the sample periods for the three instruments as best as possible; however, slight uncertainty existed over the exact time each instrument started measuring when calculating mean sample windows $( \pm 30 \mathrm{~s})$. These factors combined may help to explain the slight differences observed between different instruments during this study. When multiple instruments have measured the same NMVOC in this study, preference was given to the data from the GC $\times$ GC-FID due to the ability of this instrument to resolve coeluting peaks, followed by the DC-GC-FID and then the PTR-ToF-MS.

\subsection{NMVOC emission factors from biomass fuels}

Figure 7 shows a detailed breakdown of the mean NMVOC emission factors by fuel type measured for all 76 burns (see Sect. S3 for values). Emission factors have been determined by calculating the mean NMVOC concentrations up the flue over a 30 min period, in line with the GC sample time, with any small emissions after this sample window not included. This has been related to the total volume of air convectively drawn up the flue and the mass of fuel burnt (see Sect. S4 for details). The data are split by functionality to show trends for different chemical types. This shows that burning released a large amount of different NMVOCs across a wide range of functionalities, molecular weights and volatilities. The large variety of NMVOCs are likely to have different influences on $\mathrm{O}_{3}$ formation, SOA production and the toxicity of emissions.

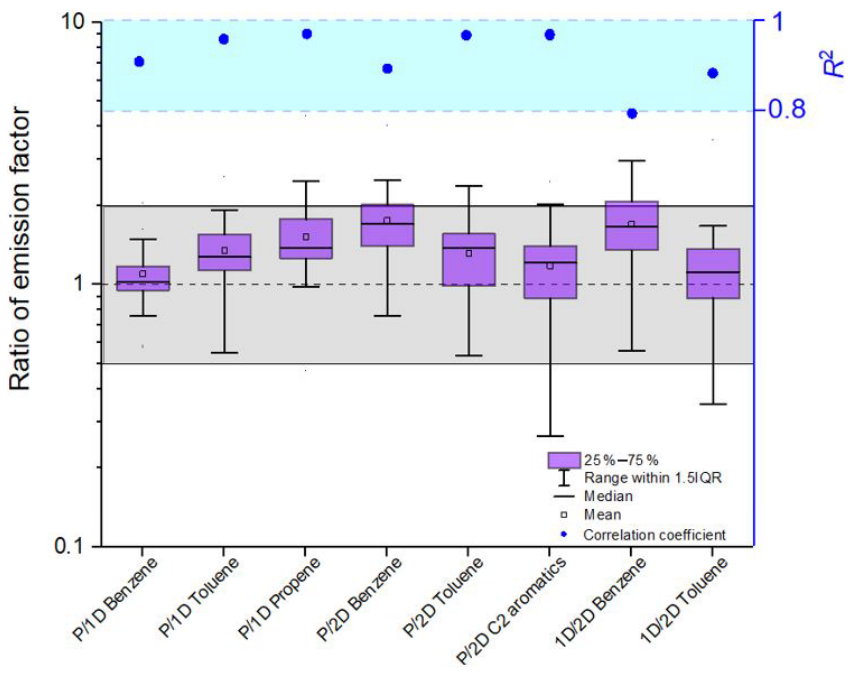

Figure 6. Comparison of PTR-ToF-MS to DC-GC-FID and GC $\times$ GC-FID with the black dashed line representing slopes equal to one, grey shaded region representing slopes agreeing within a factor of 2 and shaded blue region indicating correlation coefficients $>0.8 ; \mathrm{P}=$ PTR-ToF-MS, $1 \mathrm{D}=\mathrm{DC}-\mathrm{GC}-\mathrm{FID}$ and $2 \mathrm{D}=\mathrm{GC} \times \mathrm{GC}-$ FID.

Figure 7a shows very large emissions of smaller oxygenated species which were driven by methanol; acetic acid; and the unresolved combined peak for hydroxy acetone, methyl acetate, and ethyl formate. For the fuelwood samples, acetic acid/glycolaldehyde $\left(2.6 \mathrm{~g} \mathrm{~kg}^{-1}\right)$, methanol $\left(1.8 \mathrm{~g} \mathrm{~kg}^{-1}\right)$ and acetaldehyde $\left(0.6 \mathrm{~g} \mathrm{~kg}^{-1}\right)$ compared well with mean values reported by Koss et al. (2018) for pines, firs and spruces $\left(2.7 / 1.3 / 1.2 \mathrm{~g} \mathrm{~kg}^{-1}\right)$ and the mean values measured by Stockwell et al. (2015) mainly from crop residues, grasses and spruces $\left(1.6 / 1.3 / 0.9 \mathrm{~g} \mathrm{~kg}^{-1}\right)$. The emission factor from this study for the unresolved peak of hydroxy acetone, methyl acetate and ethyl formate $\left(1.4 \mathrm{~g} \mathrm{~kg}^{-1}\right)$ was larger than 

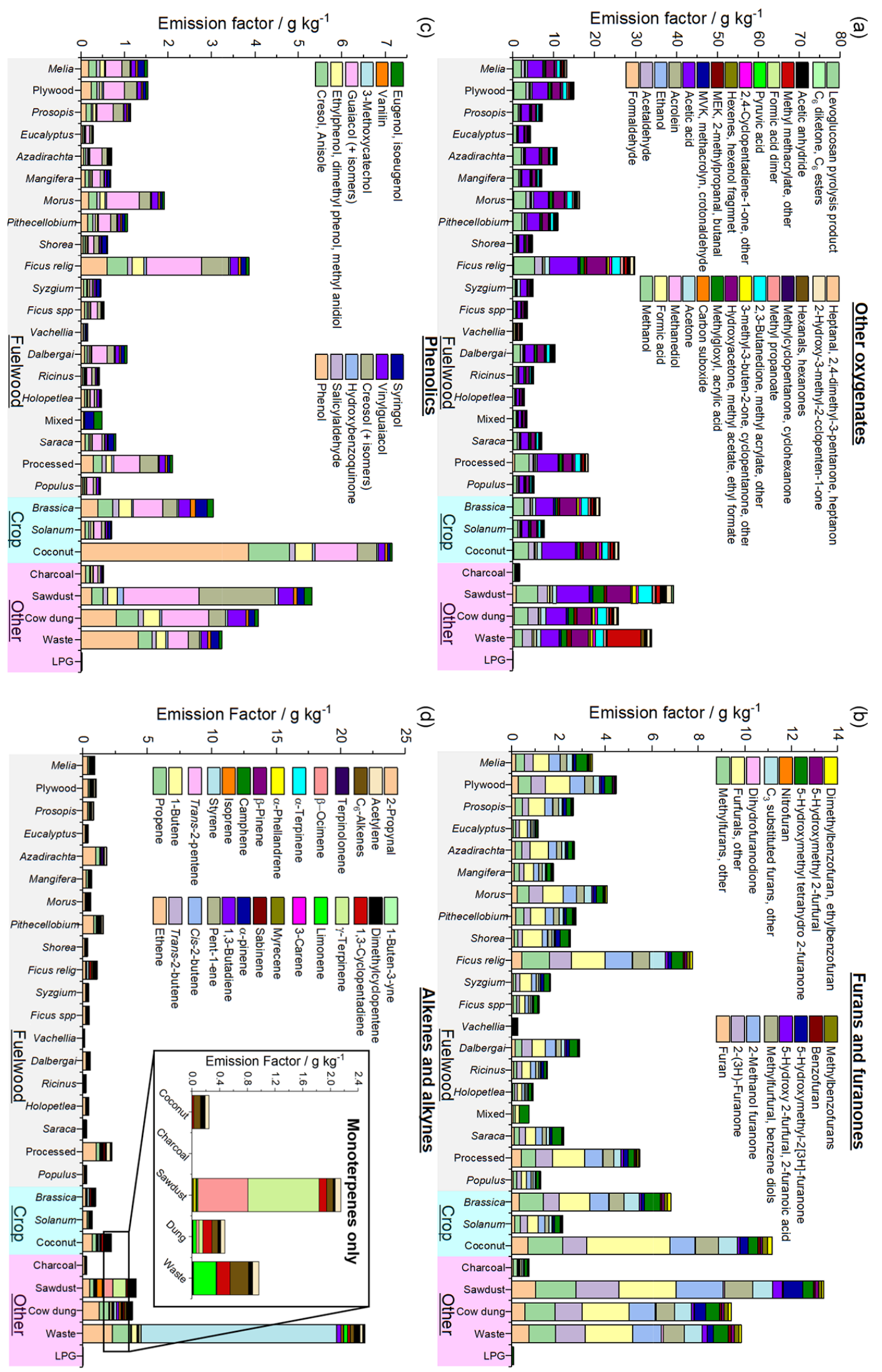

Figure 7. 

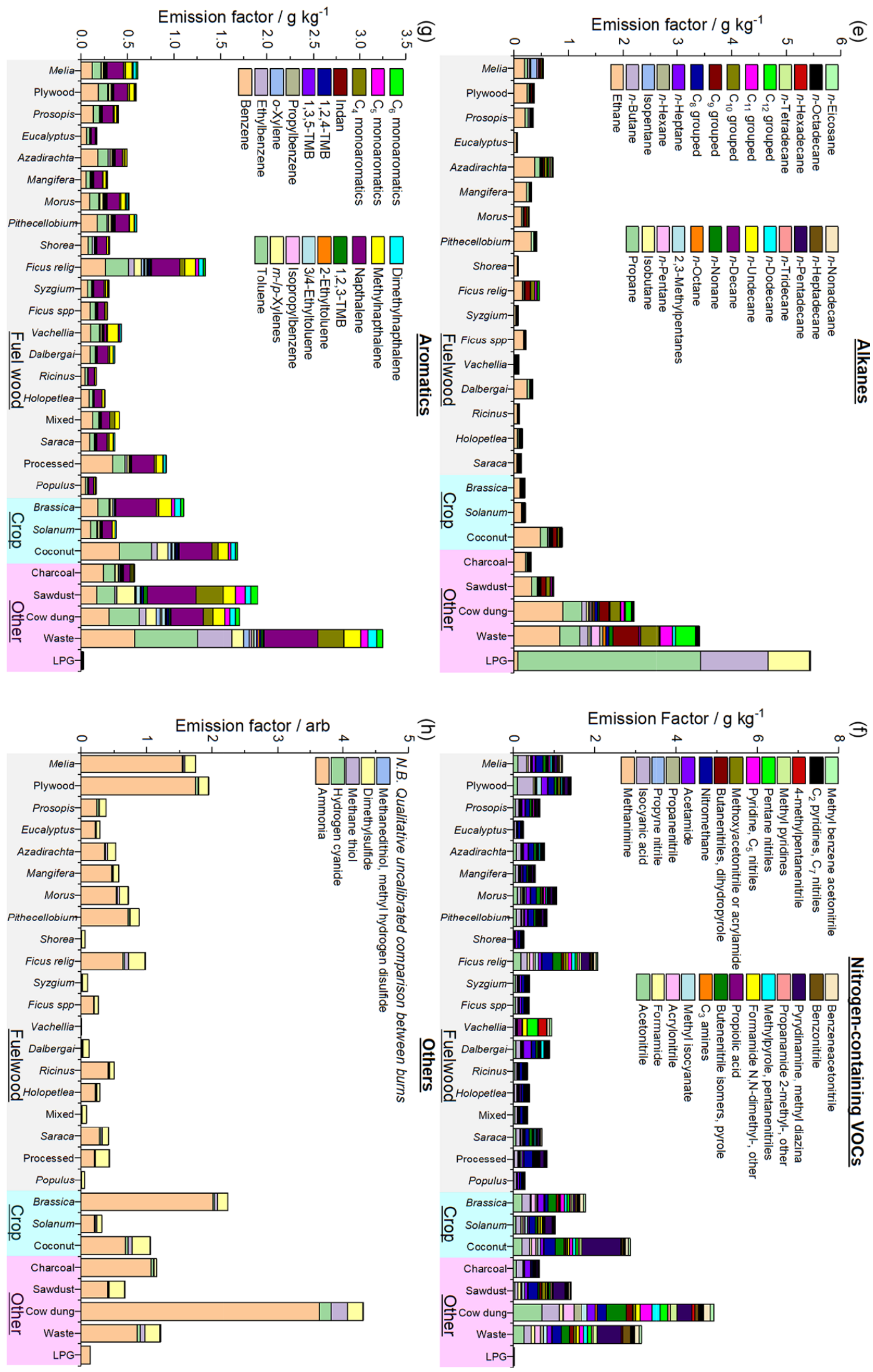

Figure 7. Measured emission factors grouped by functionality. 
those previously reported by Koss et al. (2018) and Stockwell et al. (2015) of 0.55 and $0.25 \mathrm{~g} \mathrm{~kg}^{-1}$, respectively.

Figure $7 \mathrm{~b}$ shows that there were large emissions of furans and furanones from combustion, mainly from methyl furans, furfurals, 2-(3H)-furanone, methyl furfurals and 2methanol furanone. The World Health Organization considers furan a carcinogenic species of high priority (WHO, 2016) with furan and substituted furans suspected to be toxic and mutagenic (Ravindranath et al., 1984; Peterson, 2006; Monien et al., 2011). Furan emissions originate from the low-temperature depolymerisation of hemi-cellulose (Sekimoto et al., 2018) and from large alcohols and enols in hightemperature regions of hydrocarbon flames (Johansson et al., 2016). The OH chemistry of furans has been the subject of several studies (Bierbach et al., 1994; Bierbach et al., 1995; Tapia et al., 2011; Liljegren and Stevens, 2013; Strollo and Ziemann, 2013; Zhao and Wang, 2017; Coggon et al., 2019) and often produces more reactive products such as butenedial, 4-oxo-2-pentenal and 2-methylbutenedial (Bierbach et al., 1994; Gómez Alvarez et al., 2009; Aschmann et al., 2011, 2014). Photo-oxidation of furans may also be a potentially important source of small organic acids such as formic acid (Wang et al., 2020). Oxidation can also occur by nitrate (Berndt et al., 1997; Colmenar et al., 2012) or chlorine radicals (Cabañas et al., 2005; Villanueva et al., 2007). As a result, furans have recently been shown to be some of the species with the highest $\mathrm{OH}$ reactivity from biomass burning, causing an estimated $10 \%$ of the $\mathrm{O}_{3}$ produced by the combustion emissions in the first $4 \mathrm{~h}$ after emission (Hartikainen et al., 2018; Coggon et al., 2019). Oxidation of furans can lead to SOA production (Gómez Alvarez et al., 2009; Strollo and Ziemann, 2013) with an estimated $8 \%-15 \%$ of the SOA caused by furans emitted by burning of black spruce, cut grass, Indonesian peat and ponderosa pine and $28 \%-50 \%$ of the SOA from rice straw and wire grass (Hatch et al., 2015), although SOA yields are still uncertain for many species (Hatch et al., 2017).

Phenols are formed from the low-temperature depolymerisation of lignin (Simoneit et al., 1993; Sekimoto et al., 2018), which is a polymer of randomly linked, amorphous highmolecular-weight phenolic compounds (Shafizadeh, 1982). Owing to their high emission factors and SOA formation potentials, phenolic compounds contribute significantly to SOA production from biomass burning emissions (Yee et al., 2013; Lauraguais et al., 2014; Gilman et al., 2015; Finewax et al., 2018). Figure 7c shows that the largest phenolic emissions from fuelwood in this study were methoxyphenols, with significant contributions from phenol, guaiacol, cresols and anisole. Phenolic emissions from sawdust were dominated by guaiacol and creosol. Phenolic emissions from coconut shell were greatest, most likely as a result of the lignin-rich nature of coconut shell (Pandharipande et al., 2018). The larger mean emission of furanics $\left(3.2 \mathrm{~g} \mathrm{~kg}^{-1}\right)$ compared to phenolics $\left(1.1 \mathrm{~g} \mathrm{~kg}^{-1}\right)$ from fuelwood was consistent with wood being composed of around $75 \%$ cellulose or hemi-cellulose and $25 \%$ lignin (Sjöström, 1993).

Figure $7 \mathrm{~d}$ shows that the largest alkene emission was styrene from burning municipal solid waste, likely caused by the presence of polystyrene in the fuel. Emissions of alkenes from fuelwood were dominated by ethene and propene, which are species with high photochemical ozone creation potentials (Cheng et al., 2010). Monoterpenes, which are extremely reactive with the $\mathrm{OH}$ radical (Atkinson and Arey, 2003), were emitted from combustion of sawdust, cow dung cake and municipal solid waste samples.

Ethane and propane dominated the alkane emissions for fuelwood samples (see Fig. 7e). A wider range of alkanes from $\mathrm{C}_{2}-\mathrm{C}_{20}$ were observed from combustion of coconut, cow dung cake and municipal solid waste. The largest alkane emission by mass was from LPG due to unburnt propane and butane.

Nitrogen-containing NMVOCs are formed from the volatilisation and decomposition of nitrogen-containing compounds within the fuel, mainly from free amino acids but can also be from pyrroline, pyridine and chlorophyll (Leppalahti and Koljonen, 1995; Burling et al., 2010; Ren and Zhao, 2015). Nitrogen-containing NMVOCs are of interest because nitrogen may be important in the development of new particles (Smith et al., 2008; Kirkby et al., 2011; Yu and Luo, 2014), which act as cloud condensation nuclei (Kerminen et al., 2005; Laaksonen et al., 2005; Sotiropoulou et al., 2006) and alter the hydrological cycle by forming new clouds and precipitation (Novakov and Penner, 1993). They can also contribute to light-absorbing brown carbon $(\mathrm{BrC})$ aerosol formation, effecting climate (Laskin et al., 2015). Additionally, nitrogen-containing NMVOCs can be extremely toxic (Ramírez et al., 2012, 2014; Farren et al., 2015). Cow dung cake was the largest emitter of nitrogencontaining NMVOCs $\left(4.9 \mathrm{~g} \mathrm{~kg}^{-1}\right)$, releasing large amounts of acetonitrile and nitriles, likely to have a large impact on the toxicity and chemistry of emissions (see Fig. 7f).

Figure $7 \mathrm{~g}$ shows that emissions of aromatics from fuelwood, cow dung cake and municipal solid waste were principally benzene, toluene and naphthalenes. Large emissions of benzene were unsurprising as biomass burning is the largest global benzene source (Andreae and Merlet, 2001). Emissions of benzene, toluene, ethylbenzene and xylenes (BTEX) from cow dung cake $\left(0.5-1.7 \mathrm{~g} \mathrm{~kg}^{-1}\right)$ were in line with previous measurements of $1.3 \mathrm{~g} \mathrm{~kg}^{-1}$ (Koss et al., 2018) and $1.8 \mathrm{~g} \mathrm{~kg}^{-1}$ (Fleming et al., 2018), but they were lower than the $4.5 \mathrm{~g} \mathrm{~kg}^{-1}$ reported from cow dung cake combusted from Nepal (Stockwell et al., 2016). Emissions of BTEX from municipal solid waste burning $\left(0.9-2.6 \mathrm{~g} \mathrm{~kg}^{-1}\right)$ were comparable to those measured previously $\left(3.5 \mathrm{~g} \mathrm{~kg}^{-1}\right.$ ) (Stockwell et al., 2016).

Figure $7 \mathrm{~h}$ shows a qualitative comparison of species such as ammonia, HCN and dimethyl sulfide which were measured during experiments, but they could not be accurately quantified as their sensitivity was too different from the 
NMVOCs used to build the transmission curve. Cow dung cake emitted significantly more of these species than other fuel types.

Table 2 shows the total measured emission factors of NMVOCs for different fuel types. The total measured emission factor has been calculated as the sum of the PTR-ToFMS signal, excluding reagent ion peaks $(<m / z 31 \mathrm{Th})$, water cluster peaks $(\mathrm{m} / \mathrm{z} 37 \mathrm{Th})$ and isotope peaks identified for all masses (SIS, 2016). The emission factors for all alkanes and alkenes measured by the GC instruments were also included, as alkanes up to $n$-hexane had proton affinities less than water and larger alkanes had proton affinities similar to water (Ellis and Mayhew, 2014; Wróblewski et al., 2006). This low sensitivity meant that no peaks were present in the PTR-ToF-MS spectra for these larger species. Any alkenes measured by the DC-GC-FID were excluded from the PTRToF-MS data. Further information on the species included in the calculation of the total measured emission factor is given in Sect. S5.

Coconut shell, sawdust, cow dung cake and municipal solid waste released the greatest mass of NMVOC per kilogram of fuel burnt. The mean emission factor for all fuelwood types $\left(18.7 \mathrm{~g} \mathrm{~kg}^{-1}\right)$ was comparable to that for chaparral $\left(16.6 \mathrm{~g} \mathrm{~kg}^{-1}\right)$ measured using PTR-ToF-MS by Stockwell et al. (2015). This may be due to similarities between north Indian fuelwood types with chaparral, which is characterised by hot dry summers, and mild wet winters. The mean fuelwood emission factor was smaller than Stockwell et al. (2015) reported for coniferous canopy $\left(31.0 \mathrm{~g} \mathrm{~kg}^{-1}\right)$. The NMVOC emission measured for cow dung cake $\left(62.0 \mathrm{~g} \mathrm{~kg}^{-1}\right)$ was comparable to that previously reported $\left(66.3 \mathrm{~g} \mathrm{~kg}^{-1}\right)$ in literature using PTR-ToF-MS (Koss et al., 2018) but 2-3 times larger than that measured by GCFID/ECD/MS likely due to those techniques missing significant amounts of emissions (Fleming et al., 2018). Whilst the total measured emissions reported by Fleming et al. (2018) might therefore be an underestimate, it is noteworthy that the emission factors measured by Fleming et al. (2018) in angithi stoves for cow dung cake were a factor of $\sim 4$ greater than fuelwood under the same conditions. This result was comparable to this study, which showed that cow dung cake emissions were a factor of $\sim 3$ larger than fuelwood, but the techniques used here targeted a greater proportion of total emissions. Moreover, Fleming et al. (2018) reported emission factors from combustion of biomass fuels from a neighbouring state, Haryana, and there may be slight heterogeneity between the different fuels collected in both studies. Venkataraman et al. (2010) and Koss et al. (2018) also showed NMVOC emissions from dung combustion to be greater than from fuelwood. NMVOC emissions from municipal solid waste $\left(87.3 \mathrm{~g} \mathrm{~kg}^{-1}\right)$ were significantly larger than the $\sim 9 \mathrm{~g} \mathrm{~kg}^{-1}$ (Stockwell et al., 2015) and $\sim 35 \mathrm{~g} \mathrm{~kg}^{-1}$ (Stockwell et al., 2016) previously reported. This was likely due to differences in composition and moisture content of the fuels collected from Indian landfill sites for the present study, compared with the daily mixed waste and plastic bags collected at a US fire services laboratory (Stockwell et al., 2015) and a variety of mixed waste and plastics collected from around Nepal (Stockwell et al., 2016). It seems noteworthy that combustion experiments of fuels collected from developing countries in Stockwell et al. (2016) had larger emission factors than those collected from and burnt at a laboratory (Stockwell et al., 2015). The mean crop residue combustion emission factor $\left(37.9 \mathrm{~g} \mathrm{~kg}^{-1}\right)$ was comparable to that reported by Stockwell et al. (2015), despite the small number of samples in this study and compositional differences.

Considerable uncertainties exist in consumption estimates for fuels such as cow dung cake and municipal solid waste in India. A previous study estimated that in 1985 in India fuelwood consumption was $220 \mathrm{Tg}$ and cow dung cake consumption $93 \mathrm{Tg}$ (Yevich and Logan, 2003). A different study made an India-wide estimate for 2000 which estimated fuelwood consumption to be 281 (192-409) Tg and cow dung cake consumption to be 62 (35-128) Tg (Habib et al., 2004). A more recent study estimated fuelwood usage at $256 \mathrm{Tg}$ and cow dung cake consumption at $106 \mathrm{Tg}$ for 2007 (Singh et al., 2013). Estimates of the amount of municipal solid waste burnt in India are even fewer than for cow dung cake consumption. Two previous studies have estimated that $81.4 \mathrm{Tg}$ of municipal solid waste was burnt in India in 2010 (Wiedinmyer et al., 2014) and that 68 (45-105) Tg was burnt in 2015 (Sharma et al., 2019). The mean emission factors for cow dung cake and municipal solid waste combustion were considerably larger than for fuelwood, and they highlight that at an India-wide level these may represent significant NMVOC sources.

Intermediate-volatility organic compounds (IVOCs) are defined as having effective saturation concentration, $C^{*}$, in the range $300-3 \times 10^{6} \mu \mathrm{g} \mathrm{m}^{-3}$ (Donahue et al., 2012). The $C^{*}$ of several species was estimated using a previously established approach (Lu et al., 2018), with the IVOC boundary defined in this study at benzaldehyde $(m=106.12)$, for which $C^{*}$ was $\sim 7 \times 10^{6} \mu \mathrm{g} \mathrm{m}^{-3}$. Table 2 also shows an approximation for the mean amount of IVOCs released by fuel type. This approach was approximate as vapour pressures depend on both mass and functionality. The fuels tested in this study showed that mean emissions of IVOC species represented approximately $18 \%-27 \%$ of total measured emissions from all fuel types other than LPG. This demonstrated that domestic solid-fuel combustion is potentially a large global source of IVOCs. In addition, this may represent an underestimate because, the quartz filter placed on the sample line may remove IVOC species which have partitioned to the aerosol phase due to the high aerosol concentrations present during source testing. Further studies are required to better understand the contribution of IVOC emissions from biomass burning to SOA formation. This is evaluated as part of a different study, using the dataset generated as part of this study and provided elsewhere (Stewart et al., 2021b). 
Table 2. Mean total measured NMVOC emission factors $\left(\mathrm{g} \mathrm{kg}^{-1}\right.$, including IVOC fraction) where high and low EF represent the largest and smallest emission factors, respectively, measured for a given sample type $\left(\mathrm{g} \mathrm{kg}^{-1}\right)$; IVOC is the sum of emission factors of species with a mass greater than benzaldehyde $\left(\mathrm{g} \mathrm{kg}^{-1}\right)$, where $n$ represents the number of measurements made.

\begin{tabular}{lrrrrrrr}
\hline & Wood & Dung & Waste & LPG & Charcoal & Sawdust & Crop \\
\hline NMVOC & 18.7 & 62.0 & 87.3 & 5.7 & 5.4 & 72.4 & 37.9 \\
High EF & 96.7 & 83.0 & 119.1 & 9.8 & 7.9 & 114.0 & 73.8 \\
Low EF & 4.3 & 35.3 & 56.3 & 1.9 & 2.4 & 28.3 & 8.9 \\
IVOC & 3.5 & 12.6 & 13.2 & 0.2 & 1.4 & 16.9 & 8.0 \\
$n$ & 51 & 8 & 3 & 3 & 2 & 2 & 6 \\
\hline
\end{tabular}
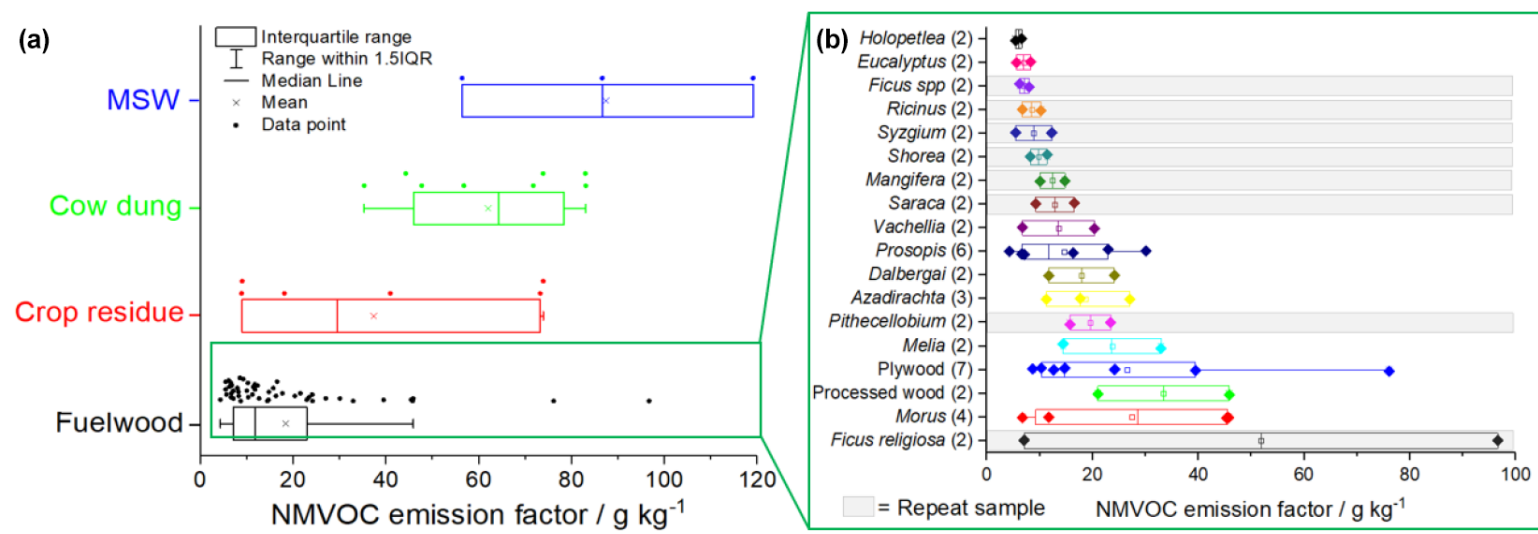

Figure 8. Variability in NMVOC emission factor by fuel type. (a) Range of emission factors measured for fuelwood, cow dung cake, crop residue and municipal solid waste samples with boxplots showing the mean, median, interquartile range and range within 1.5IQR and solid circles showing the spread of measured emission factors by fuel type. (b) Zoomed-in green region displaying range of NMVOC emission factors measured for individual species of fuelwood with the grey shaded region indicating repeat samples from the same sample collection location and diamonds indicating the measured NMVOC emission factors.

Figure 8a shows the distribution of total measured NMVOC emission factors for fuelwood, cow dung cake, crop residues and municipal solid waste (MSW). Boxplots show the mean, median, interquartile range and range within 1.5IQR. The solid circles display the spread of measured emission factors by fuel type. The zoomed-in green region given in Fig. 8b specifically focuses on the variability in emission factors of individual species of fuelwood, which has been explored in detail due to the large number of samples. Repeat samples collected from the same location are shaded in grey. For fuelwood, measured NMVOC emission factors varied by over a factor of 20 between $4.3-96.7 \mathrm{~g} \mathrm{~kg}^{-1}$. The NMVOC emission factors showed a right-skewed distribution with a median of $11.7 \mathrm{~g} \mathrm{~kg}^{-1}$, mean of $18.7 \mathrm{~g} \mathrm{~kg}^{-1}$ and an interquartile range of $15.3 \mathrm{~g} \mathrm{~kg}^{-1}$. For repeat measurements of identical species of fuelwood collected at the same location, except for Ficus religiosa, measured emission factors from repeat experiments varied over a much smaller range, by up to a factor of 2.3. Variation between emissions from these samples were likely due to different moisture contents of actual samples measured and the specific combustion conditions of individual burns. The large variation observed for Ficus religiosa was likely due to the samples be- ing significantly different in terms of composition. Despite the samples for Holoptelea spp. and Eucalyptus spp. coming from different locations, emission factors for these samples were quite reproducible and only varied by a factor of $1.2-1.5$. For the remaining identical species of fuelwood collected from different locations, emission factors varied over a much larger range by factors of $\sim 2-9$.

For the crop residue species studied here, NMVOC emissions were right skewed with a median of $29.5 \mathrm{~g} \mathrm{~kg}^{-1}$, which was less than the mean of $37.9 \mathrm{~g} \mathrm{~kg}^{-1}$ and varied from $8.9-$ $73.8 \mathrm{~g} \mathrm{~kg}^{-1}$ with an interquartile range of $53.9 \mathrm{~g} \mathrm{~kg}^{-1}$. Cocos nucifera and Solanum melongena were repeat measurements of fuel collected from the same location and varied by factors of 1.8-2. NMVOC emissions from Brassica spp. fuel, which was collected from different locations, varied by a factor of $\sim 8$. Cow dung cake and MSW samples were all collected from different locations and varied by up to factors of 2.4 and 2.1 , respectively.

Figure 9a shows the mean total emissions measured in this study for different fuel types split by functionality. Large variability in total measured emissions were observed for fuelwood, with emission factors from individual burns varying by a factor of $\sim 20$. Figure $9 \mathrm{~b}$ shows the mean 
(a)

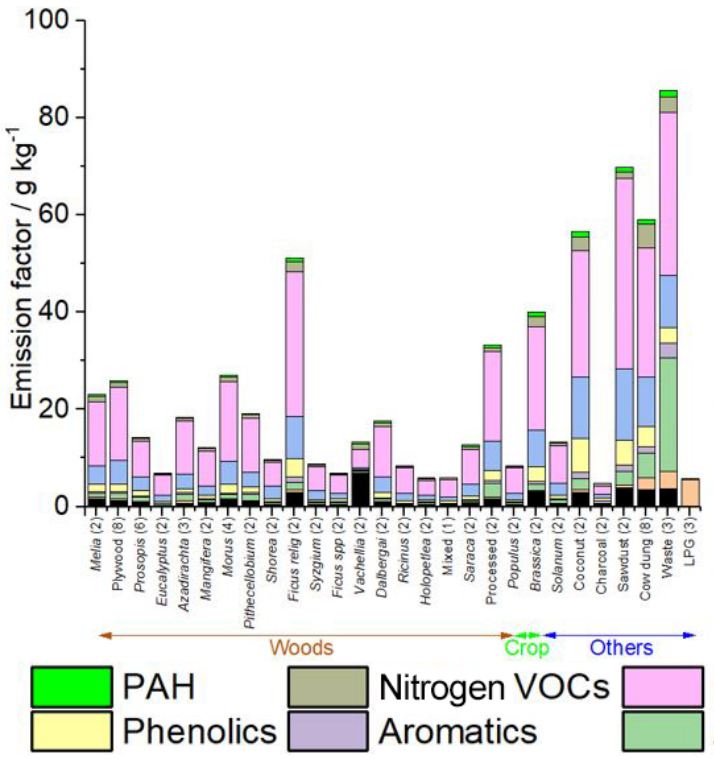

(b)

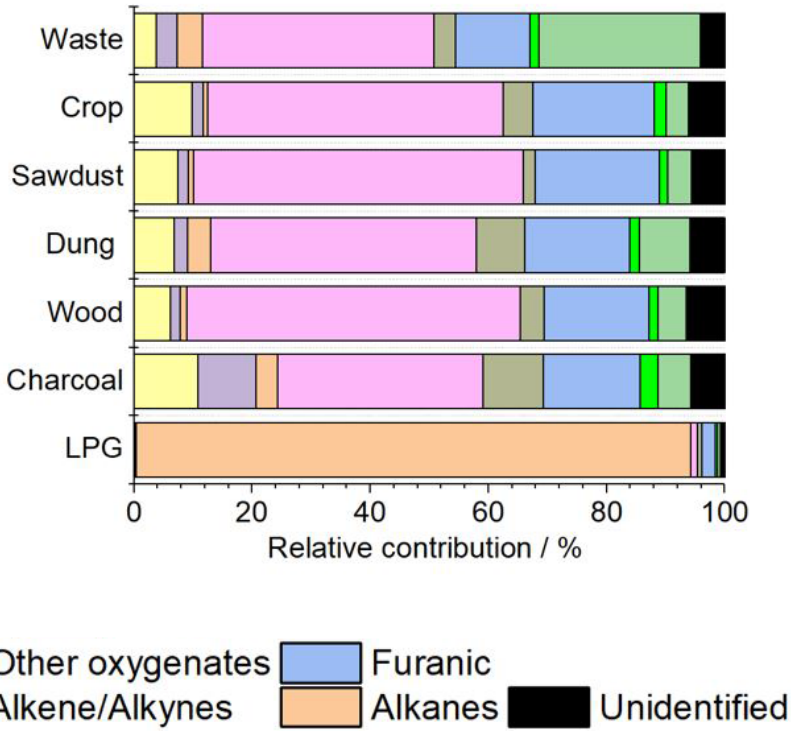

Figure 9. NMVOC emissions from burning sources in Delhi, India, grouped by functionality with unidentified emissions given by the total NMVOC signal measured by the PTR-ToF-MS minus the fraction quantified using DC-GC-FID, GC $\times$ GC-FID, GC $\times$ GC-ToF-MS and PTR-ToF-MS instruments with (a) all fuel types and (b) mean values by type of fuel.

emissions by functionality as a proportion of total measured emissions averaged by overall fuel type. Oxygenates were the largest emission ( $33 \%-55 \%)$, followed by furanic compounds $(16 \%-21 \%)$, phenolics $(6 \%-12 \%)$ and aromatics (2\%-9\%) for all fuel types except LPG. LPG emissions were mainly alkanes, with a small emission of furanic species. These have previously been reported to be produced in hydrocarbon flames (Johansson et al., 2016).

Figure $9 \mathrm{a}$ and $\mathrm{b}$ also show the amount of NMVOCs which remained unidentified (black). On average $94 \%$ of all measured NMVOCs emitted across all burns were speciated. Speciation was greater than $90 \%$ for all sample types, except Vachellia spp. due to several large unidentified peaks (see Sect. S6). Mean speciation by fuel type was between $93 \%-96 \%$ for all other fuels, except LPG where speciation was $>99 \%$.

\subsection{Emission ratios}

The ratio of the mixing ratios of NMVOCs in the emitted gas can be a useful indicator of their source(s) in ambient air. Ratios can be specific to sources and can allow one source to be distinguished from another. The ratio of $i-/ n$-pentane can be a useful indicator of whether emissions are anthropogenic or from biomass burning, with a ratio 2.2-3.8 indicative of vehicular emissions, $0.8-0.9$ for natural gas drilling, 1.8-4.6 for evaporative fuel emissions and $<1$ from burning (Stewart et al., 2021a). Benzene/toluene ratios can also be useful and have been reported from traffic exhaust to be around 0.3 (Hedberg et al., 2002).

$i$ - / $n$-Pentane indicator ratios have been evaluated for fuelwood sources, propane/butane ratios for LPG, and benzene/toluene ratios for fuelwood and cow dung cake (see Fig. 10). The range of values for multiple different burns has been evaluated rather than just reporting mean and median ratios. The median of $i$ - / $n$-pentane ratios from biomass samples measured during this study was $\sim 0.7$ (see Fig. 10). The mean ratio was $\sim 1.0$, with an interquartile range (IQR) of $\sim 0.5-1.5$, which suggests caution is required when assigning burning sources based on emission ratios due to considerable variability. Despite this, the ratio from solidfuel combustion sources was often less than expected from petrol emissions. The mean ratio of propane/butane from LPG burning was measured to be 3.1. The ratios of benzene/toluene varied considerably between different sources and was measured for fuelwood combustion (2.3), cow dung cake combustion (0.94), petrol liquid fuel $(0.40)$ and diesel liquid fuel (0.20). The range of benzene/toluene ratios for fuelwood was large, with an IQR of $\sim 1.5-2.8$ and the range within 1.5IQR shown by the whiskers in Fig. 10 from $\sim 0.9$ 4.2. Despite the variability of ratios from specific source types, the considerable range of benzene/toluene ratios could potentially be a useful indicator of the origin of unaged (fresh) ambient emissions in Delhi. However, further study would be required to assess whether these ratios were also true in the exhaust of petrol and diesel vehicles in India or just limited to fugitive emissions. These findings agree well 


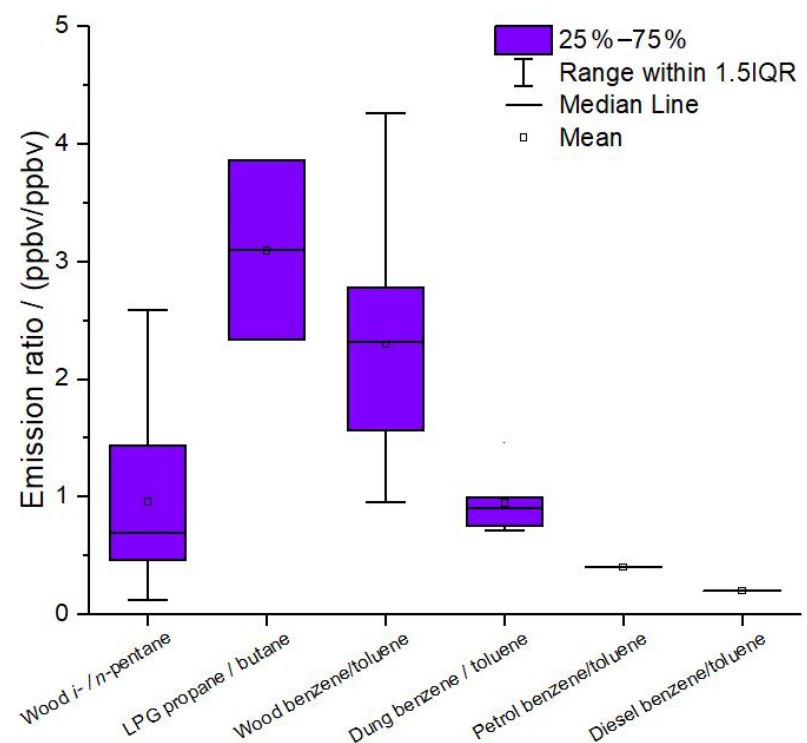

Figure 10. Summary of ratios of NMVOCs measured during this study from the burning of fuelwood, LPG and cow dung cake and from the headspace of liquid petrol and diesel fuels collected in India. The different mean and median values have been considered to evaluate the ratios at emission of specific sources.

with literature which report mean benzene/toluene ratios of 1.4-5.0 from fuelwood and 0.3 from automotive emissions (Hedberg et al., 2002), indicating that on average biomass burning releases a greater molar ratio of benzene than toluene when compared to automotive emissions.

\section{Conclusions}

This study is based on comprehensive measurements of NMVOC emissions using a range of detailed and complementary techniques across a large range of functionalities and volatilities. It presents detailed burning emission factors for different NMVOCs from a range of fuels used in the Delhi area of India for residential combustion. This work allows for a better understanding of the impact of residential combustion on air quality and shows that fuelwood, cow dung cake and municipal solid waste burning sources release significantly more NMVOCs than LPG.

A range of areas where future studies are required to better improve and understand emissions from burning are highlighted here:

1. Better understanding of stove burn conditions on emissions

The impact of stove conditions on NMVOC emissions remains poorly understood. Experiments in this study were carried out using expert local judgement to attempt to ensure that laboratory conditions reflected real-world burning conditions. A range of stoves are used in India for combustion of local fuels, such as chulha and angithi stoves, and an evaluation of the impact of these on emissions and their relative use and spatial distribution requires further study.

2. Better understanding of the effect of moisture content on modified combustion efficiency

Fuels in this study were collected and stored in a manner designed to be reflective of local practices to ensure that laboratory combustion conditions, and in turn emissions, reflected local burning practices. Future studies should conduct detailed compositional analysis of fuel types and moisture content prior to burning. These studies should also measure $\mathrm{CO}$ and $\mathrm{CO}_{2}$ to allow for an evaluation of the impact of modified combustion efficiency on emissions from different fuel types.

\section{Limited measurements of some fuel types}

Few measurements were made from domestic, commercial and industrial waste, and the emission factors measured in this study were higher than those observed in previous studies. The effect of moisture content on waste burning has been suggested to impact emissions of particulate matter by around an order of magnitude (Jayarathne et al., 2018). Furthermore, only one LPG stove was used to evaluate emissions from this fuel source, with emissions likely to vary by the type of burner used. Future studies should also make more measurements from waste burning to better understand the effect of composition on emissions. Comprehensive measurements should also be made of emissions from combustion of a range of additional crop residues, as these are an important NMVOC source in India (Jain et al., 2014).

4. Evaluation of the impact on $\mathrm{O}_{3}$ and SOA production as well as the toxicity of emissions

Better understanding of the drivers of photochemical $\mathrm{O}_{3}$ and SOA production from burning emissions is required. A large variety of high-molecular-weight species with likely low volatilities, such as phenolic and furanic compounds, were released from burning. These NMVOCs are expected to have a large influence on subsequent atmospheric chemistry, and a detailed understanding of this chemistry is required to truly assess the impact of biomass burning on air quality. The SOA production potential and $\mathrm{OH}$ reactivity of emissions from these fuels are examined as part of a further study (Stewart et al., 2021b).

5. Evaluation of the relative importance of fuel types to air quality in India

Detailed evaluation of fuel use across India is required to evaluate the relative impact of emissions from fuelwood, municipal solid waste, cow dung cakes and LPG. 
The emission factors measured for cow dung cake and municipal solid waste in this study were much higher than for fuelwood and LPG and indicated that these sources are likely to contribute significantly to poor air quality.

The comprehensive characterisation of emissions from fuel types in this study should be used to produce spatially disaggregated local emission inventories to provide better inputs into regional policy and global chemical transport models. This should allow for a better understanding of the key drivers of poor air quality in India and could allow for meaningful mitigation strategies to alleviate the poor air quality observed.

Data availability. The emission factors measured as part of this study are provided in the Supplement.

Video supplement. An illustrative example of the burn conditions used in this study are given in the video supplement at https://doi.org/10.5446/50203 (Stewart, 2020).

Supplement. The supplement related to this article is available online at: https://doi.org/10.5194/acp-21-2383-2021-supplement.

Author contributions. GJS made measurements with $\mathrm{GC} \times \mathrm{GC}$ FID, combined and analysed datasets, and led the writing of the article. WJFA made measurements of NMVOCs by PTR-ToF-MS, supported by CNH, LKS and NT. BSN made measurements with DC-GC, supported by JRH. ARV assisted with the running and organising of experiments. RA, AM, RJ, SA, LY and SKS collected fuels, carried out burning experiments and measured gas volumes up the flue. RED worked on the GC $\times$ GC-FID method development. SSMY assisted with data interpretation. EN, NM, RG, ARR and JDL worked on logistics and data interpretation. TKM and JFH provided overall guidance with setup, conducting, running and interpreting experiments. All authors contributed to the discussion, writing and editing of the article.

Competing interests. The authors declare that they have no conflict of interest.

Disclaimer. The paper does not discuss policy issues, and the conclusions drawn in the paper are based on interpretation of results by the authors and in no way reflect the viewpoint of the funding agencies.

Acknowledgements. This work was supported by the NewtonBhabha fund administered by the UK Natural Environment Research Council, through the DelhiFlux project of the Atmospheric Pollution and Human Health in an Indian Megacity (APHH-India) programme. The authors gratefully acknowledge the financial support provided by the UK Natural Environment Research Council and the Earth System Science Organization, Ministry of Earth Sciences, Government of India, under the Indo-UK Joint Collaboration (grant nos. NE/P016502/1 and MoES/16/19/2017/APHH) (DelhiFlux). Gareth J. Stewart and Beth S. Nelson acknowledge the NERC SPHERES doctoral training programme for studentships. Rahul Arya, Arnab Mondal, Ritu Jangirh, Sakshi Ahlawat, Lokesh Yadav, Sudhir K. Sharma and Tuhin K. Mandal are thankful to the Director's Office, CSIR-National Physical Laboratory, New Delhi, for allowing them to carry out this work. The authors thank the National Centre for Atmospheric Science for providing the DC-GCFID instrument. Lokesh K. Sahu acknowledges the Physical Research Laboratory (PRL), Ahmedabad, India, for the support and permission to deploy PTR-ToF-MS during the experimental campaign.

Financial support. This research has been supported by the Natural Environment Research Council (grant no. NE/P016502/1) and the Ministry of Earth Sciences (grant no. MoES/16/19/2017/APHH, DelhiFlux).

Review statement. This paper was edited by Alex Lee and reviewed by two anonymous referees.

\section{References}

Akagi, S. K., Yokelson, R. J., Wiedinmyer, C., Alvarado, M. J., Reid, J. S., Karl, T., Crounse, J. D., and Wennberg, P. O.: Emission factors for open and domestic biomass burning for use in atmospheric models, Atmos. Chem. Phys., 11, 4039-4072, https://doi.org/10.5194/acp-11-4039-2011, 2011.

Akhtar, T., Uah, Z., Khan, M. H., and Nazli, R.: Chronic bronchitis in women using solid biomass fuel in rural peshawar, Pakistan, Chest, 132, 1472-1475, https://doi.org/10.1378/chest.062529, 2007.

Alvarado, M. J., Lonsdale, C. R., Yokelson, R. J., Akagi, S. K., Coe, H., Craven, J. S., Fischer, E. V., McMeeking, G. R., Seinfeld, J. H., Soni, T., Taylor, J. W., Weise, D. R., and Wold, C. E.: Investigating the links between ozone and organic aerosol chemistry in a biomass burning plume from a prescribed fire in California chaparral, Atmos. Chem. Phys., 15, 6667-6688, https://doi.org/10.5194/acp-15-6667-2015, 2015.

Andreae, M. O.: Emission of trace gases and aerosols from biomass burning - an updated assessment, Atmos. Chem. Phys., 19, 8523-8546, https://doi.org/10.5194/acp-19-8523-2019, 2019.

Andreae, M. O. and Merlet, P.: Emission of trace gases and aerosols from biomass burning, Global Biogeochem. Cy., 15, 955-966, https://doi.org/10.1029/2000GB001382, 2001.

Aschmann, S. M., Nishino, N., Arey, J., and Atkinson, R.: Kinetics of the Reactions of OH Radicals with 2- and 3-Methylfuran, 2,3and 2,5-Dimethylfuran, and E- and Z-3-Hexene-2,5-dione, and Products of $\mathrm{OH}+2,5$-Dimethylfuran, Environ. Sci. Technol., 45, 1859-1865, https://doi.org/10.1021/es103207k, 2011.

Aschmann, S. M., Nishino, N., Arey, J., and Atkinson, R.: Products of the $\mathrm{OH}$ Radical-Initiated Reactions of Furan, 
2- and 3-Methylfuran, and 2,3- and 2,5-Dimethylfuran in the Presence of NO, J. Phys. Chem. A, 118, 457-466, https://doi.org/10.1021/jp410345k, 2014.

Atkinson, R. and Arey, J.: Atmospheric Degradation of Volatile Organic Compounds, Chem. Rev., 103, 4605-4638, https://doi.org/10.1021/cr0206420, 2003.

Barabad, M. L. M., Jung, W., Versoza, M. E., Kim, M., Ko, S., Park, D., and Lee, K.: Emission Characteristics of Particulate Matter, Volatile Organic Compounds, and Trace Elements from the Combustion of Coals in Mongolia, Int. J. Env. Res. Pub. He., 15, 1706, https://doi.org/10.3390/ijerph15081706, 2018.

Bautista, L. E., Correa, A., Baumgartner, J., Breysse, P., and Matanoski, G. M.: Indoor Charcoal Smoke and Acute Respiratory Infections in Young Children in the Dominican Republic, Am. J. Epidemiol., 169, 572-580, https://doi.org/10.1093/aje/kwn372, 2009.

Berndt, T., Böge, O., and Rolle, W.: Products of the Gas-Phase Reactions of $\mathrm{NO}_{3}$ Radicals with Furan and Tetramethylfuran, Environ. Sci. Technol., 31, 1157-1162, https://doi.org/10.1021/es960669z, 1997.

Bierbach, A., Barnes, I., Becker, K. H., and Wiesen, E.: Atmospheric chemistry of unsaturated carbonyls-butenedial, 4-oxo2-pentenal, 3-hexene-2,5-diome, maleic-anhydride, 3H-furan-2one and 5-methyl-3H-furan-2-one, Environ. Sci. Technol., 28, 715-729, https://doi.org/10.1021/es00053a028, 1994.

Bierbach, A., Barnes, I., and Becker, K. H.: Product and kinetic study of the $\mathrm{OH}$-initiated gas-phase oxidation of Furan, 2-methylfuran and furanaldehydes at $300 \mathrm{~K}$, Atmos. Environ., 29, 2651-2660, https://doi.org/10.1016/1352-2310(95)00096-H, 1995.

Bond, T. C., Doherty, S. J., Fahey, D. W., Forster, P. M., Berntsen, T., De Angelo, B. J., Flanner, M. G., Ghan, S., Kärcher, B., Koch, D., Kinne, S., Kondo, Y., Quinn, P. K., Sarofim, M. C., Schultz, M. G., Schulz, M., Venkataraman, C., Zhang, H., Zhang, S., Bellouin, N., Guttikunda, S. K., Hopke, P. K., Jacobson, M. Z., Kaiser, J. W., Klimont, Z., Lohmann, U., Schwarz, J. P., Shindell, D., Storelvmo, T., Warren, S. G., and Zender, C. S.: Bounding the role of black carbon in the climate system: A scientific assessment, J. Geophys. Res.-Atmos., 118, 5380-5552, https://doi.org/10.1002/jgrd.50171, 2013.

Boy, E., Bruce, N., and Delgado, H.: Birth weight and exposure to kitchen wood smoke during pregnancy in rural Guatemala, Environ. Health Persp., 110, 109-114, https://doi.org/10.1289/ehp.02110109, 2002.

Brilli, F., Gioli, B., Ciccioli, P., Zona, D., Loreto, F., Janssens, I. A., and Ceulemans, R.: Proton Transfer Reaction Time-of-Flight Mass Spectrometric (PTR-TOF-MS) determination of volatile organic compounds (VOCs) emitted from a biomass fire developed under stable nocturnal conditions, Atmos. Environ., 97, 5467, https://doi.org/10.1016/j.atmosenv.2014.08.007, 2014.

Bruns, E. A., El Haddad, I., Slowik, J. G., Kilic, D., Klein, F., Baltensperger, U., and Prévôt, A. S. H.: Identification of significant precursor gases of secondary organic aerosols from residential wood combustion, Sci. Rep.-UK, 6, 27881, https://doi.org/10.1038/srep27881, 2016.

Burling, I. R., Yokelson, R. J., Griffith, D. W. T., Johnson, T. J., Veres, P., Roberts, J. M., Warneke, C., Urbanski, S. P., Reardon, J., Weise, D. R., Hao, W. M., and de Gouw, J.: Laboratory measurements of trace gas emissions from biomass burning of fuel types from the southeastern and southwestern United States, Atmos. Chem. Phys., 10, 11115-11130, https://doi.org/10.5194/acp-10-11115-2010, 2010.

Cabañas, B., Villanueva, F., Martín, P., Baeza, M. T., Salgado, S., and Jiménez, E.: Study of reaction processes of furan and some furan derivatives initiated by $\mathrm{Cl}$ atoms, Atmos. Environ., 39, 1935-1944, https://doi.org/10.1016/j.atmosenv.2004.12.013, 2005.

Chafe, Z. A., Brauer, M., Klimont, Z., Van Dingenen, R., Mehta, S., Rao, S., Riahi, K., Dentener, F., and Smith, K. R.: Household Cooking with Solid Fuels Contributes to Ambient $\mathrm{PM}_{2.5}$ Air Pollution and the Burden of Disease, Environ. Health Persp., 122, 1314-1320, https://doi.org/10.1289/ehp.1206340, 2014

Chen, J., Li, C., Ristovski, Z., Milic, A., Gu, Y., Islam, M. S., Wang, S., Hao, J., Zhang, H., He, C., Guo, H., Fu, H., Miljevic, B., Morawska, L., Thai, P., Lam, Y. F., Pereira, G., Ding, A., Huang, X., and Dumka, U. C.: A review of biomass burning: Emissions and impacts on air quality, health and climate in China, Sci. Total Environ., 579, 1000-1034, https://doi.org/10.1016/j.scitotenv.2016.11.025, 2017.

Cheng, H. R., Guo, H., Saunders, S. M., Lam, S. H. M., Jiang, F., Wang, X. M., Simpson, I. J., Blake, D. R., Louie, P. K. K., and Wang, T. J.: Assessing photochemical ozone formation in the Pearl River Delta with a photochemical trajectory model, Atmos. Environ., 44, 4199-4208, https://doi.org/10.1016/j.atmosenv.2010.07.019, 2010.

Christian, T. J., Yokelson, R. J., Cárdenas, B., Molina, L. T., Engling, G., and Hsu, S.-C.: Trace gas and particle emissions from domestic and industrial biofuel use and garbage burning in central Mexico, Atmos. Chem. Phys., 10, 565-584, https://doi.org/10.5194/acp-10-565-2010, 2010.

Coggon, M. M., Lim, C. Y., Koss, A. R., Sekimoto, K., Yuan, B., Gilman, J. B., Hagan, D. H., Selimovic, V., Zarzana, K. J., Brown, S. S., Roberts, J. M., Müller, M., Yokelson, R., Wisthaler, A., Krechmer, J. E., Jimenez, J. L., Cappa, C., Kroll, J. H., de Gouw, J., and Warneke, C.: OH chemistry of non-methane organic gases (NMOGs) emitted from laboratory and ambient biomass burning smoke: evaluating the influence of furans and oxygenated aromatics on ozone and secondary NMOG formation, Atmos. Chem. Phys., 19, 1487514899, https://doi.org/10.5194/acp-19-14875-2019, 2019.

Colmenar, I., Cabañas, B., Martínez, E., Salgado, M. S., and Martín, P.: Atmospheric fate of a series of furanaldehydes by their $\mathrm{NO}_{3}$ reactions, Atmos. Environ., 54, 177-184, https://doi.org/10.1016/j.atmosenv.2012.02.087, 2012.

Crutzen, P. J., Heidt, L. E., Krasnec, J. P., Pollock, W. H., and Seiler, W.: Biomass burning as a source of atmospheric gases $\mathrm{CO}, \mathrm{H}_{2}, \mathrm{~N}_{2} \mathrm{O}, \mathrm{NO}, \mathrm{CH}_{3} \mathrm{Cl}$ and $\mathrm{COS}$, Nature, 282, 253-256, https://doi.org/10.1038/282253a0, 1979.

Dennis, R. J., Maldonado, D., Norman, S., Baena, E., and Martinez, G.: Woodsmoke Exposure and Risk for Obstructive Airways Disease Among Women, Chest, 109, 115-119, https://doi.org/10.1378/chest.109.1.115, 1996.

Donahue, N. M., Kroll, J. H., Pandis, S. N., and Robinson, A. L.: A two-dimensional volatility basis set - Part 2: Diagnostics of organic-aerosol evolution, Atmos. Chem. Phys., 12, 615-634, https://doi.org/10.5194/acp-12-615-2012, 2012.

Dunmore, R. E., Hopkins, J. R., Lidster, R. T., Lee, J. D., Evans, M. J., Rickard, A. R., Lewis, A. C., and Hamilton, J. F.: 
Diesel-related hydrocarbons can dominate gas phase reactive carbon in megacities, Atmos. Chem. Phys., 15, 9983-9996, https://doi.org/10.5194/acp-15-9983-2015, 2015.

Ellis, A. M. and Mayhew, C. A.: Proton Transfer Reaction Mass Spectrometry: Principles and Applications, John Wiley \& Sons Ltd., Chichester, UK, 2014.

Elzein, A., Stewart, G. J., Swift, S. J., Nelson, B. S., Crilley, L. R., Alam, M. S., Reyes-Villegas, E., Gadi, R., Harrison, R. M., Hamilton, J. F., and Lewis, A. C.: A comparison of $\mathrm{PM}_{2.5}$-bound polycyclic aromatic hydrocarbons in summer Beijing (China) and Delhi (India), Atmos. Chem. Phys., 20, 14303-14319, https://doi.org/10.5194/acp-20-14303-2020, 2020.

EPA: Greenhouse gases from small-scale combustion devices in devloping countries: phase IIA household stoves in India, Research Triangle Park, NC, USA, 2000.

Farren, N. J., Ramírez, N., Lee, J. D., Finessi, E., Lewis, A. C., and Hamilton, J. F.: Estimated Exposure Risks from Carcinogenic Nitrosamines in Urban Airborne Particulate Matter, Environ. Sci. Technol., 49, 9648-9656, https://doi.org/10.1021/acs.est.5b01620, 2015.

Finewax, Z., de Gouw, J. A., and Ziemann, P. J.: Identification and Quantification of 4-Nitrocatechol Formed from $\mathrm{OH}$ and $\mathrm{NO}_{3}$ Radical-Initiated Reactions of Catechol in Air in the Presence of $\mathrm{NO}_{x}$ : Implications for Secondary Organic Aerosol Formation from Biomass Burning, Environ. Sci. Technol., 52, 1981-1989, https://doi.org/10.1021/acs.est.7b05864, 2018.

Fleming, L. T., Weltman, R., Yadav, A., Edwards, R. D., Arora, N. K., Pillarisetti, A., Meinardi, S., Smith, K. R., Blake, D. R., and Nizkorodov, S. A.: Emissions from village cookstoves in Haryana, India, and their potential impacts on air quality, Atmos. Chem. Phys., 18, 15169-15182, https://doi.org/10.5194/acp-1815169-2018, 2018.

Fullerton, D. G., Bruce, N., and Gordon, S. B.: Indoor air pollution from biomass fuel smoke is a major health concern in the developing world, T. Roy. Soc. Trop. Med. H., 102, 843-851, https://doi.org/10.1016/j.trstmh.2008.05.028, 2008.

Garaga, R., Sahu, S. K., and Kota, S. H.: A Review of Air Quality Modeling Studies in India: Local and Regional Scale, Current Pollution Reports, 4, 59-73, https://doi.org/10.1007/s40726018-0081-0, 2018.

Gilman, J. B., Lerner, B. M., Kuster, W. C., Goldan, P. D., Warneke, C., Veres, P. R., Roberts, J. M., de Gouw, J. A., Burling, I. R., and Yokelson, R. J.: Biomass burning emissions and potential air quality impacts of volatile organic compounds and other trace gases from fuels common in the US, Atmos. Chem. Phys., 15, 13915-13938, https://doi.org/10.5194/acp-15-139152015, 2015.

Gómez Alvarez, E., Borrás, E., Viidanoja, J., and Hjorth, J.: Unsaturated dicarbonyl products from the $\mathrm{OH}$-initiated photo-oxidation of furan, 2-methylfuran and 3-methylfuran, Atmos. Environ., 43, 1603-1612, https://doi.org/10.1016/j.atmosenv.2008.12.019, 2009.

Gould, C. F. and Urpelainen, J.: LPG as a clean cooking fuel: Adoption, use, and impact in rural India, Energ. Policy, 122, 395-408, https://doi.org/10.1016/j.enpol.2018.07.042, 2018.

Habib, G., Venkataraman, C., Shrivastava, M., Banerjee, R., Stehr, J. W., and Dickerson, R. R.: New methodology for estimating biofuel consumption for cooking: Atmospheric emissions of black carbon and sulfur dioxide from India, Global Biogeochem Cy., 18, GB3007, https://doi.org/10.1029/2003GB002157, 2004.

Hartikainen, A., Yli-Pirilä, P., Tiitta, P., Leskinen, A., Kortelainen, M., Orasche, J., Schnelle-Kreis, J., Lehtinen, K. E. J., Zimmermann, R., Jokiniemi, J., and Sippula, O.: Volatile Organic Compounds from Logwood Combustion: Emissions and Transformation under Dark and Photochemical Aging Conditions in a Smog Chamber, Environ. Sci. Technol., 52, 4979-4988, https://doi.org/10.1021/acs.est.7b06269, 2018.

Hatch, L. E., Luo, W., Pankow, J. F., Yokelson, R. J., Stockwell, C. E., and Barsanti, K. C.: Identification and quantification of gaseous organic compounds emitted from biomass burning using two-dimensional gas chromatography-time-offlight mass spectrometry, Atmos. Chem. Phys., 15, 1865-1899, https://doi.org/10.5194/acp-15-1865-2015, 2015.

Hatch, L. E., Yokelson, R. J., Stockwell, C. E., Veres, P. R., Simpson, I. J., Blake, D. R., Orlando, J. J., and Barsanti, K. C.: Multi-instrument comparison and compilation of non-methane organic gas emissions from biomass burning and implications for smoke-derived secondary organic aerosol precursors, Atmos. Chem. Phys., 17, 1471-1489, https://doi.org/10.5194/acp17-1471-2017, 2017.

Hatch, L. E., Rivas-Ubach, A., Jen, C. N., Lipton, M., Goldstein, A. H., and Barsanti, K. C.: Measurements of I/SVOCs in biomass-burning smoke using solid-phase extraction disks and two-dimensional gas chromatography, Atmos. Chem. Phys., 18, 17801-17817, https://doi.org/10.5194/acp-18-17801-2018, 2018.

Hays, M. D., Geron, C. D., Linna, K. J., Smith, N. D., and Schauer, J. J.: Speciation of Gas-Phase and Fine Particle Emissions from Burning of Foliar Fuels, Environ. Sci. Technol., 36, 2281-2295, https://doi.org/10.1021/es0111683, 2002.

Hedberg, E., Kristensson, A., Ohlsson, M., Johansson, C., Johansson, P.-A., Swietlicki, E., Vesely, V., Wideqvist, U., and Westerholm, R.: Chemical and physical characterization of emissions from birch wood combustion in a wood stove, Atmos. Environ., 36, 4823-4837, https://doi.org/10.1016/S1352-2310(02)00417X, 2002.

Holzinger, R.: PTRwid: A new widget tool for processing PTR-TOF-MS data, Atmos. Meas. Tech., 8, 3903-3922, https://doi.org/10.5194/amt-8-3903-2015, 2015.

Hopkins, J., Lewis, A., and Read, K.: A two-column method for long-term monitoring of non-methane hydrocarbons (NMHCs) and oxygenated volatile organic compounds (o-VOCs), J. Environ. Monitor., 5, 8-13, https://doi.org/10.1039/b202798d, 2003.

Isotope Distribution Calculator and Mass Spec Plotter: https://www. sisweb.com/mstools/isotope.htm (last access: 14 July 2020), 2016.

Jaffe, D. A. and Wigder, N. L.: Ozone production from wildfires: A critical review, Atmos. Environ., 51, 1-10, https://doi.org/10.1016/j.atmosenv.2011.11.063, 2012.

Jain, N., Bhatia, A., and Pathak, H.: Emission of Air Pollutants from Crop Residue Burning in India, Aerosol Air Qual. Res., 14, 422 430, https://doi.org/10.4209/aaqr.2013.01.0031, 2014.

Jayarathne, T., Stockwell, C. E., Bhave, P. V., Praveen, P. S., Rathnayake, C. M., Islam, Md. R., Panday, A. K., Adhikari, S., Maharjan, R., Goetz, J. D., De Carlo, P. F., Saikawa, E., Yokelson, R. J., and Stone, E. A.: Nepal Ambient Monitoring and Source Testing Experiment (NAMaSTE): emissions of particu- 
late matter from wood- and dung-fueled cooking fires, garbage and crop residue burning, brick kilns, and other sources, Atmos. Chem. Phys., 18, 2259-2286, https://doi.org/10.5194/acp18-2259-2018, 2018.

Johansson, K. O., Dillstrom, T., Monti, M., El Gabaly, F., Campbell, M. F., Schrader, P. E., Popolan-Vaida, D. M., RichardsHenderson, N. K., Wilson, K. R., Violi, A., and Michelsen, H. A.: Formation and emission of large furans and oxygenated hydrocarbons from flames, P. Natl. Acad. Sci. USA, 113, 8374-8379, https://doi.org/10.1073/pnas.1604772113, 2016.

Kerminen, V.-M., Lihavainen, H., Komppula, M., Viisanen, Y., and Kulmala, M.: Direct observational evidence linking atmospheric aerosol formation and cloud droplet activation, Geophys. Res. Lett., 32, L14803, https://doi.org/10.1029/2005g1023130, 2005.

Kirkby, J., Curtius, J., Almeida, J., Dunne, E., Duplissy, J., Ehrhart, S., Franchin, A., Gagne, S., Ickes, L., Kurten, A., Kupc, A., Metzger, A., Riccobono, F., Rondo, L., Schobesberger, S., Tsagkogeorgas, G., Wimmer, D., Amorim, A., Bianchi, F., Breitenlechner, M., David, A., Dommen, J., Downard, A., Ehn, M., Flagan, R. C., Haider, S., Hansel, A., Hauser, D., Jud, W., Junninen, H., Kreissl, F., Kvashin, A., Laaksonen, A., Lehtipalo, K., Lima, J., Lovejoy, E. R., Makhmutov, V., Mathot, S., Mikkila, J., Minginette, P., Mogo, S., Nieminen, T., Onnela, A., Pereira, P., Petaja, T., Schnitzhofer, R., Seinfeld, J. H., Sipila, M., Stozhkov, Y., Stratmann, F., Tome, A., Vanhanen, J., Viisanen, Y., Vrtala, A., Wagner, P. E., Walther, H., Weingartner, E., Wex, H., Winkler, P. M., Carslaw, K. S., Worsnop, D. R., Baltensperger, U., and Kulmala, M.: Role of sulphuric acid, ammonia and galactic cosmic rays in atmospheric aerosol nucleation, Nature, 476, 429-477, https://doi.org/10.1038/nature10343, 2011.

Ko, Y. C., Lee, C. H., Chen, M. J., Huang, C. C., Chang, W. Y., Lin, H. J., Wang, H. Z., and Chang, P. Y.: Risk factors for primary lung cancer among non-smoking women in Taiwan, Int. J. Epidemiol., 26, 24-31, https://doi.org/10.1093/ije/26.1.24, 1997.

Kodros, J. K., Carter, E., Brauer, M., Volckens, J., Bilsback, K. R., L'Orange, C., Johnson, M., and Pierce, J. R.: Quantifying the Contribution to Uncertainty in Mortality Attributed to Household, Ambient, and Joint Exposure to $\mathrm{PM}_{2.5}$ From Residential Solid Fuel Use, GeoHealth, 2, 25-39, https://doi.org/10.1002/2017gh000115, 2018.

Koss, A. R., Sekimoto, K., Gilman, J. B., Selimovic, V., Coggon, M. M., Zarzana, K. J., Yuan, B., Lerner, B. M., Brown, S. S., Jimenez, J. L., Krechmer, J., Roberts, J. M., Warneke, C., Yokelson, R. J., and de Gouw, J.: Non-methane organic gas emissions from biomass burning: identification, quantification, and emission factors from PTR-ToF during the FIREX 2016 laboratory experiment, Atmos. Chem. Phys., 18, 3299-3319, https://doi.org/10.5194/acp-18-3299-2018, 2018.

Kroll, J. H. and Seinfeld, J. H.: Chemistry of secondary organic aerosol: Formation and evolution of low-volatility organics in the atmosphere, Atmos. Environ., 42, 3593-3624, https://doi.org/10.1016/j.atmosenv.2008.01.003, 2008.

Kumar, V., Chandra, B. P., and Sinha, V.: Large unexplained suite of chemically reactive compounds present in ambient air due to biomass fires, Sci. Rep.-UK, 8, 626, https://doi.org/10.1038/s41598-017-19139-3, 2018.

Kurokawa, J. and Ohara, T.: Long-term historical trends in air pollutant emissions in Asia: Regional Emission inventory in
ASia (REAS) version 3, Atmos. Chem. Phys., 20, 12761-12793, https://doi.org/10.5194/acp-20-12761-2020, 2020.

Kurokawa, J., Ohara, T., Morikawa, T., Hanayama, S., JanssensMaenhout, G., Fukui, T., Kawashima, K., and Akimoto, H.: Emissions of air pollutants and greenhouse gases over Asian regions during 2000-2008: Regional Emission inventory in ASia (REAS) version 2, Atmos. Chem. Phys., 13, 11019-11058, https://doi.org/10.5194/acp-13-11019-2013, 2013.

Laaksonen, A., Hamed, A., Joutsensaari, J., Hiltunen, L., Cavalli, F., Junkermann, W., Asmi, A., Fuzzi, S., and Facchini, M. C.: Cloud condensation nucleus production from nucleation events at a highly polluted region, Geophys. Res. Lett., 32, L06812, https://doi.org/10.1029/2004gl022092, 2005.

Laskin, A., Laskin, J., and Nizkorodov, S. A.: Chemistry of Atmospheric Brown Carbon, Chem. Rev., 115, 4335-4382, https://doi.org/10.1021/cr5006167, 2015.

Lauraguais, A., Coeur, C., Cassez, A., Deboudt, K., Fourmentin, M., and Choël, M.: Atmospheric reactivity of hydroxyl radicals with guaiacol (2-methoxyphenol), a biomass burning emitted compound: Secondary organic aerosol formation and gas-phase oxidation products, Atmos. Environ., 86, 155-163, https://doi.org/10.1016/j.atmosenv.2013.11.074, 2014.

Lee, B. H., Lopez-Hilfiker, F. D., Mohr, C., Kurtén, T., Worsnop, D. R., and Thornton, J. A.: An Iodide-Adduct HighResolution Time-of-Flight Chemical-Ionization Mass Spectrometer: Application to Atmospheric Inorganic and Organic Compounds, Environ. Sci. Technol., 48, 6309-6317, https://doi.org/10.1021/es500362a, 2014.

Leco: ChromaTOF 5.0, available at: https://www.leco.com/product/ chromatof-software (last access: 10 August 2020), 2019.

Leppalahti, J. and Koljonen, T.: Nitrogen evolution from coal, peat and wood during gasification - literature review, Fuel Process. Technol., 43, 1-45, https://doi.org/10.1016/03783820(94)00123-b, 1995.

Lerner, B. M., Gilman, J. B., Aikin, K. C., Atlas, E. L., Goldan, P. D., Graus, M., Hendershot, R., Isaacman-Van Wertz, G. A., Koss, A., Kuster, W. C., Lueb, R. A., McLaughlin, R. J., Peischl, J., Sueper, D., Ryerson, T. B., Tokarek, T. W., Warneke, C., Yuan, B., and de Gouw, J. A.: An improved, automated whole air sampler and gas chromatography mass spectrometry analysis system for volatile organic compounds in the atmosphere, Atmos. Meas. Tech., 10, 291-313, https://doi.org/10.5194/amt-10291-2017, 2017.

Lewis, A., Hopkins, J., Carslaw, D., Hamilton, J., Nelson, B., Stewart, G., Dernie, J., Passant, N., and Murrells, T.: An increasing role for solvent emissions and implications for future measurements of Volatile Organic Compounds, Philos. T. R. Soc. S.-A, 378, 2183, https://doi.org/10.1098/rsta.2019.0328, 2020.

Liljegren, J. and Stevens, P.: Kinetics of the Reaction of OH Radicals with 3-Methylfuran at Low Pressure, Int. J. Chem. Kinet., 45, 787-794, https://doi.org/10.1002/kin.20814, 2013.

Lim, S. S., Vos, T., Flaxman, A. D., Danaei, G., Shibuya, K., AdairRohani, H., AlMazroa, M. A., Amann, M., Anderson, H. R., Andrews, K. G., Aryee, M., Atkinson, C., Bacchus, L. J., Bahalim, A. N., Balakrishnan, K., Balmes, J., Barker-Collo, S., Baxter, A., Bell, M. L., Blore, J. D., Blyth, F., Bonner, C., Borges, G., Bourne, R., Boussinesq, M., Brauer, M., Brooks, P., Bruce, N. G., Brunekreef, B., Bryan-Hancock, C., Bucello, C., Buchbinder, R., Bull, F., Burnett, R. T., Byers, T. E., Calabria, B., Carapetis, 
J., Carnahan, E., Chafe, Z., Charlson, F., Chen, H., Chen, J. S., Cheng, A. T.-A., Child, J. C., Cohen, A., Colson, K. E., Cowie, B. C., Darby, S., Darling, S., Davis, A., Degenhardt, L., Dentener, F., Des Jarlais, D. C., Devries, K., Dherani, M., Ding, E. L., Dorsey, E. R., Driscoll, T., Edmond, K., Ali, S. E., Engell, R. E., Erwin, P. J., Fahimi, S., Falder, G., Farzadfar, F., Ferrari, A., Finucane, M. M., Flaxman, S., Fowkes, F. G. R., Freedman, G., Freeman, M. K., Gakidou, E., Ghosh, S., Giovannucci, E., Gmel, G., Graham, K., Grainger, R., Grant, B., Gunnell, D., Gutierrez, H. R., Hall, W., Hoek, H. W., Hogan, A., Hosgood, H. D., Hoy, D., Hu, H., Hubbell, B. J., Hutchings, S. J., Ibeanusi, S. E., Jacklyn, G. L., Jasrasaria, R., Jonas, J. B., Kan, H., Kanis, J. A., Kassebaum, N., Kawakami, N., Khang, Y.-H., Khatibzadeh, S., Khoo, J.-P., Kok, C., Laden, F., Lalloo, R., Lan, Q., Lathlean, T., Leasher, J. L., Leigh, J., Li, Y., Lin, J. K., Lipshultz, S. E., London, S., Lozano, R., Lu, Y., Mak, J., Malekzadeh, R., Mallinger, L., Marcenes, W., March, L., Marks, R., Martin, R., McGale, P., McGrath, J., Mehta, S., Memish, Z. A., Mensah, G. A., Merriman, T. R., Micha, R., Michaud, C., Mishra, V., Hanafiah, K. M., Mokdad, A. A., Morawska, L., Mozaffarian, D., Murphy, T., Naghavi, M., Neal, B., Nelson, P. K., Nolla, J. M., Norman, R., Olives, C., Omer, S. B., Orchard, J., Osborne, R., Ostro, B., Page, A., Pandey, K. D., Parry, C. D. H., Passmore, E., Patra, J., Pearce, N., Pelizzari, P. M., Petzold, M., Phillips, M. R., Pope, D., Pope, C. A., Powles, J., Rao, M., Razavi, H., Rehfuess, E. A., Rehm, J. T., Ritz, B., Rivara, F. P., Roberts, T., Robinson, C., RodriguezPortales, J. A., Romieu, I., Room, R., Rosenfeld, L. C., Roy, A., Rushton, L., Salomon, J. A., Sampson, U., Sanchez-Riera, L., Sanman, E., Sapkota, A., Seedat, S., Shi, P., Shield, K., Shivakoti, R., Singh, G. M., Sleet, D. A., Smith, E., Smith, K. R., Stapelberg, N. J. C., Steenland, K., Stöckl, H., Stovner, L. J., Straif, K., Straney, L., Thurston, G. D., Tran, J. H., Van Dingenen, R., van Donkelaar, A., Veerman, J. L., Vijayakumar, L., Weintraub, R., Weissman, M. M., White, R. A., Whiteford, H., Wiersma, S. T., Wilkinson, J. D., Williams, H. C., Williams, W., Wilson, N., Woolf, A. D., Yip, P., Zielinski, J. M., Lopez, A. D., Murray, C. J. L., and Ezzati, M.: A comparative risk assessment of burden of disease and injury attributable to 67 risk factors and risk factor clusters in 21 regions, 1990-2010: a systematic analysis for the Global Burden of Disease Study 2010, Lancet, 380, 2224-2260, https://doi.org/10.1016/S0140-6736(12)61766-8, 2012.

Liu, Q., Sasco, A. J., Riboli, E., and Hu, M. X.: Indoor Air Pollution and Lung Cancer in Guangzhou, People's Republic of China, Am. J. Epidemiol., 137, 145-154, https://doi.org/10.1093/oxfordjournals.aje.a116654, 1993.

Liu, S. M., Zhou, Y. M., Wang, X. P., Wang, D. L., Lu, J. C., Zheng, J. P., Zhong, N. S., and Ran, P. X.: Biomass fuels are the probable risk factor for chronic obstructive pulmonary disease in rural South China, Thorax, 62, 889-897, https://doi.org/10.1136/thx.2006.061457, 2007.

Lu, Q., Zhao, Y., and Robinson, A. L.: Comprehensive organic emission profiles for gasoline, diesel, and gas-turbine engines including intermediate and semi-volatile organic compound emissions, Atmos. Chem. Phys., 18, 17637-17654, https://doi.org/10.5194/acp-18-17637-2018, 2018.

McDonald, J. D., Zielinska, B., Fujita, E. M., Sagebiel, J. C., Chow, J. C., and Watson, J. G.: Fine Particle and Gaseous Emission Rates from Residential Wood Combustion, Environ. Sci. Technol., 34, 2080-2091, https://doi.org/10.1021/es9909632, 2000.
Mishra, V.: Indoor air pollution from biomass combustion and acute respiratory illness in preschool age children in Zimbabwe, Int J. Epidemiol., 32, 847-853, https://doi.org/10.1093/ije/dyg240, 2003.

Monien, B. H., Herrmann, K., Florian, S., and Glatt, H.: Metabolic activation of furfuryl alcohol: formation of 2-methylfuranyl DNA adducts in Salmonella typhimurium strains expressing human sulfotransferase 1A1 and in FVB/N mice, Carcinogenesis, 32, 1533-1539, https://doi.org/10.1093/carcin/bgr126, 2011.

Moran-Mendoza, O., Pérez-Padilla, J., Salazar-Flores, M., and Vazquez-Alfaro, F.: Wood smoke-associated lung disease: A clinical, functional, radiological and pathological description, Int. J. Tuberc. Lung. D., 12, 1092-1098, 2008.

Mukhopadhyay, R., Sambandam, S., Pillarisetti, A., Jack, D., Mukhopadhyay, K., Balakrishnan, K., Vaswani, M., Bates, M. N., Kinney, P., Arora, N., and Smith, K.: Cooking practices, air quality, and the acceptability of advanced cookstoves in Haryana, India: an exploratory study to inform large-scale interventions, Global Health Action, 5, 19016, https://doi.org/10.3402/gha.v5i0.19016, 2012.

Naeher, L. P., Brauer, M., Lipsett, M., Zelikoff, J. T., Simpson, C. D., Koenig, J. Q., and Smith, K. R.: Woodsmoke Health Effects: A Review, Inhal. Toxicol., 19, 67-106, https://doi.org/10.1080/08958370600985875, 2007.

N'Dri, A. B., Kone, A. W., Loukou, S. K. K., Barot, S., and Gignoux, J.: Carbon and nutrient losses through biomass burning, and links with soild fertility and yam (dioscorea alata) production, Exp. Agr., 55, 738-751, https://doi.org/10.1017/s0014479718000327, 2019.

Novakov, T. and Penner, J. E.: Large contribution of organic aerosols to cloud-condensation-nuclei concentrations, Nature, 365, 823-826, https://doi.org/10.1038/365823a0, 1993.

Olivier, J. G. J., Van Aardenne, J. A., Dentener, F. J., Pagliari, V., Ganzeveld, L. N., and Peters, J. A. H. W.: Recent trends in global greenhouse gas emissions: regional trends 1970-2000 and spatial distribution of key sources in 2000, Environm. Sci., 2, 81-99, https://doi.org/10.1080/15693430500400345, 2005.

Orozco-Levi, M., Garcia-Aymerich, J., Villar, J., RamírezSarmiento, A., Antó, J. M., and Gea, J.: Wood smoke exposure and risk of chronic obstructive pulmonary disease, Eur. Respir. J., 27, 542, https://doi.org/10.1183/09031936.06.00052705, 2006.

Pandey, A., Sadavarte, P., Rao, A., and Venkataraman, C.: Trends in multi-pollutant emissions from a technologylinked inventory for India: II. Residential, agricultural and informal industry sectors, Atmos. Environ., 99, 341-352, https://doi.org/10.1016/j.atmosenv.2014.09.080, 2014.

Pandharipande, S., Gujrati, M., Mulkutkar, N., and Pandey, S.: Comparative study of extraction \& characterization of lignin from wet and dry coconut husk, International journal of Engineering Sciences \& Research Technology, 7, 659-666, https://doi.org/10.5281/zenodo.1228694, 2018.

Pant, P. and Harrison, R. M.: Critical review of receptor modelling for particulate matter: A case study of India, Atmos. Environ., 49, 1-12, https://doi.org/10.1016/j.atmosenv.2011.11.060, 2012.

Perez Padilla, R., Regalado, J., Vedal, S., Pare, P., Chapela, R., Sansores, R., and Selman, M.: Exposure to biomass smoke and chronic airway disease in Mexican women - A case-control study, Am. J. Resp. Crit. Care, 154, 701-706, https://doi.org/10.1164/ajrccm.154.3.8810608, 1996. 
Peterson, L. A.: Electrophilic Intermediates Produced by Bioactivation of Furan, Drug Metab. Rev., 38, 615-626, https://doi.org/10.1080/03602530600959417, 2006.

Pfister, G. G., Wiedinmyer, C., and Emmons, L. K.: Impacts of the fall 2007 California wildfires on surface ozone: Integrating local observations with global model simulations, Geophys. Res. Lett., 35, L19814, https://doi.org/10.1029/2008GL034747, 2008.

Ponette-Gonzalez, A. G., Curran, L. M., Pittman, A. M., Carlson, K. M., Steele, B. G., Ratnasari, D., Mujiman, and Weathers, K. C.: Biomass burning drives atmospheric nutrient redistribution within forested peatlands in Borneo, Environ. Res. Lett., 11, 085003, https://doi.org/10.1088/1748-9326/11/8/085003, 2016.

Priestley, M., Le Breton, M., Bannan, T. J., Leather, K. E., Bacak, A., Reyes-Villegas, E., De Vocht, F., Shallcross, B. M. A., Brazier, T., Anwar Khan, M., Allan, J., Shallcross, D. E., Coe, H., and Percival, C. J.: Observations of Isocyanate, Amide, Nitrate, and Nitro Compounds From an Anthropogenic Biomass Burning Event Using a ToF-CIMS, J. Geophys. Res.-Atmos., 123, 76877704, https://doi.org/10.1002/2017JD027316, 2018.

Ramírez, N., Özel, M. Z., Lewis, A. C., Marcé, R. M., Borrull, F., and Hamilton, J. F.: Determination of nicotine and $\mathrm{N}$-nitrosamines in house dust by pressurized liquid extraction and comprehensive gas chromatography - Nitrogen chemiluminiscence detection, J. Chromatogr. A, 1219, 180-187, https://doi.org/10.1016/j.chroma.2011.11.017, 2012.

Ramírez, N., Özel, M. Z., Lewis, A. C., Marcé, R. M., Borrull, F., and Hamilton, J. F.: Exposure to nitrosamines in thirdhand tobacco smoke increases cancer risk in non-smokers, Environ. Int., 71, 139-147, https://doi.org/10.1016/j.envint.2014.06.012, 2014.

Ramirez-Venegas, A., Sansores, R. H., Perez-Padilla, R., Regalado, J., Velazquez, A., Sanchez, C., and Mayar, M. E.: Survival of patients with chronic obstructive pulmonary disease due to biomass smoke and tobacco, Am. J. Resp. Crit. Care, 173, 393397, https://doi.org/10.1164/rccm.200504-5680C, 2006.

Ravindranath, V., Boyd, M. R., and Burka, L. T.: Reactive metabolites from the bioactivation of toxic methylfurans, Science, 224, 884-886, https://doi.org/10.1126/science.6719117, 1984.

Ren, Q. Q. and Zhao, C. S.: Evolution of fuel-N in gas phase during biomass pyrolysis, Renew. Sust. Energ. Rev., 50, 408-418, https://doi.org/10.1016/j.rser.2015.05.043, 2015.

Rinne, S. T., Rodas, E. J., Bender, B. S., Rinne, M. L., Simpson, J. M., Galer-Unti, R., and Glickman, L. T.: Relationship of pulmonary function among women and children to indoor air pollution from biomass use in rural Ecuador, Resp. Med., 100, 12081215, https://doi.org/10.1016/j.rmed.2005.10.020, 2006.

Rubin, J. I., Kean, A. J., Harley, R. A., Millet, D. B., and Goldstein, A. H.: Temperature dependence of volatile organic compound evaporative emissions from motor vehicles, J. Geophys. Res.Atmos., 111, D03305, https://doi.org/10.1029/2005jd006458, 2006.

Sahu, L. K. and Saxena, P.: High time and mass resolved PTRTOF-MS measurements of VOCs at an urban site of India during winter: Role of anthropogenic, biomass burning, biogenic and photochemical sources, Atmos. Res., 164-165, 84-94, https://doi.org/10.1016/j.atmosres.2015.04.021, 2015.

Sahu, L. K., Yadav, R., and Pal, D.: Source identification of VOCs at an urban site of western India: Effect of marathon events and anthropogenic emissions, J. Geophys. Res.-Atmos., 121, 24162433, https://doi.org/10.1002/2015jd024454, 2016.
Saud, T., Mandal, T. K., Gadi, R., Singh, D. P., Sharma, S. K., Saxena, M., and Mukherjee, A.: Emission estimates of particulate matter $(\mathrm{PM})$ and trace gases $\left(\mathrm{SO}_{2}\right.$, $\mathrm{NO}$ and $\mathrm{NO}_{2}$ ) from biomass fuels used in rural sector of Indo-Gangetic Plain, India, Atmos. Environ., 45, 5913-5923, https://doi.org/10.1016/j.atmosenv.2011.06.031, 2011.

Saud, T., Gautam, R., Mandal, T. K., Gadi, R., Singh, D. P., Sharma, S. K., Dahiya, M., and Saxena, M.: Emission estimates of organic and elemental carbon from household biomass fuel used over the Indo-Gangetic Plain (IGP), India, Atmos. Environ., 61, 212-220, https://doi.org/10.1016/j.atmosenv.2012.07.030, 2012.

Sekimoto, K., Koss, A. R., Gilman, J. B., Selimovic, V., Coggon, M. M., Zarzana, K. J., Yuan, B., Lerner, B. M., Brown, S. S., Warneke, C., Yokelson, R. J., Roberts, J. M., and de Gouw, J.: High- and low-temperature pyrolysis profiles describe volatile organic compound emissions from western US wildfire fuels, Atmos. Chem. Phys., 18, 9263-9281, https://doi.org/10.5194/acp18-9263-2018, 2018.

Shafizadeh, F.: Introduction to pyrolysis of biomass, J. Anal. Appl. Pyrol., 3, 283-305, https://doi.org/10.1016/01652370(82)80017-X, 1982.

Sharma, G., Sinha, B., Pallavi, Hakkim, H., Chandra, B. P., Kumar, A., and Sinha, V.: Gridded Emissions of $\mathrm{CO}, \mathrm{NO}_{x}, \mathrm{SO}_{2}, \mathrm{CO}_{2}$, $\mathrm{NH}_{3}, \mathrm{HCl}, \mathrm{CH}_{4}, \mathrm{PM}_{2.5}, \mathrm{PM}_{10}, \mathrm{BC}$, and NMVOC from Open Municipal Waste Burning in India, Environ. Sci. Technol., 53, 4765-4774, https://doi.org/10.1021/acs.est.8b07076, 2019.

Sharma, S., Goel, A., Gupta, D., Kumar, A., Mishra, A., Kundu, S., Chatani, S., and Klimont, Z.: Emission inventory of non-methane volatile organic compounds from anthropogenic sources in India, Atmos. Environ., 102, 209-219, https://doi.org/10.1016/j.atmosenv.2014.11.070, 2015.

Simoneit, B. R. T., Rogge, W. F., Mazurek, M. A., Standley, L. J., Hildemann, L. M., and Cass, G. R.: Lignin pyrolysis products, lignans, and resin acids as specific tracers of plant classes in emissions from biomass combustion, Environ. Sci. Technol., 27, 2533-2541, https://doi.org/10.1021/es00048a034, 1993.

Singh, D. P., Gadi, R., Mandal, T. K., Saud, T., Saxena, M., and Sharma, S. K.: Emissions estimates of PAH from biomass fuels used in rural sector of IndoGangetic Plains of India, Atmos. Environ., 68, 120-126, https://doi.org/10.1016/j.atmosenv.2012.11.042, 2013.

Sirithian, D., Thepanondh, S., Sattler, M. L., and Laowagul, W.: Emissions of volatile organic compounds from maize residue open burning in the northern region of Thailand, Atmos. Environ., 176, 179-187, https://doi.org/10.1016/j.atmosenv.2017.12.032, 2018.

Sjöström, E.: Wood Chemistry: Fundamentals and Applications, 2nd ed., Academic Press, San Diego, USA, 1993.

Smith, J. N., Dunn, M. J., Van Reken, T. M., Iida, K., Stolzenburg, M. R., McMurry, P. H., and Huey, L. G.: Chemical composition of atmospheric nanoparticles formed from nucleation in Tecamac, Mexico: Evidence for an important role for organic species in nanoparticle growth, Geophys. Res. Lett., 35, L04808, https://doi.org/10.1029/2007gl032523, 2008.

Smith, K. R., McCracken, J. P., Weber, M. W., Hubbard, A., Jenny, A., Thompson, L. M., Balmes, J., Diaz, A., Arana, B., and Bruce, N.: Effect of reduction in household air pollution on childhood pneumonia in Guatemala (RESPIRE): 
a randomised controlled trial, The Lancet, 378, 1717-1726, https://doi.org/10.1016/S0140-6736(11)60921-5, 2011.

Smith, K. R., Bruce, N., Balakrishnan, K., Adair-Rohani, H., Balmes, J., Chafe, Z., Dherani, M., Hosgood, H. D., Mehta, S., Pope, D., and Rehfuess, E.: Millions Dead: How Do We Know and What Does It Mean? Methods Used in the Comparative Risk Assessment of Household Air Pollution, Annu. Rev. Publ. Health, 35, 185-206, https://doi.org/10.1146/annurevpublhealth-032013-182356, 2014.

Sotiropoulou, R. E. P., Tagaris, E., Pilinis, C., Anttila, T., and Kulmala, M.: Modeling New Particle Formation During Air Pollution Episodes: Impacts on Aerosol and Cloud Condensation Nuclei, Aerosol Sci. Tech., 40, 557-572, https://doi.org/10.1080/02786820600714346, 2006.

Srivastava, A., Joseph, A. E., More, A., and Patil, S.: Emissions of VOCs at Urban Petrol Retail Distribution Centres in India (Delhi and Mumbai), Environ. Monit. Assess., 109, 227-242, https://doi.org/10.1007/s10661-005-6292-z, 2005.

Stewart, G. J.: Non-methane volatile organic compound measurements from domestic biomass burning by PTR-TOF-MS, TIB AV-Portal, https://doi.org/10.5446/50203, 2020.

Stewart, G. J., Nelson, B. S., Drysdale, W. S., Acton, W. J. F., Vaughan, A. R., Hopkins, J. R., Dunmore, R. E., Hewitt, C. N., Nemitz, E. G., Mullinger, N., Langford, B., Shivani, Villegas, E. R., Gadi, R., Rickard, A. R., Lee, J. D., and Hamilton, J. F.: Sources of non-methane hydrocarbons in surface air in Delhi, India, Faraday Discuss., https://doi.org/10.1039/D0FD00087F, online first, 2021a.

Stewart, G. J., Nelson, B. S., Acton, W. J. F., Vaughan, A. R., Hopkins, J. R., Yunus, S. S. M., Hewitt, C. N., Nemitz, E., Mullinger, N., Gadi, R., Rickard, A. R., Lee, J. D., Mandal, T. K., and Hamilton, J. F.: Comprehensive organic emission profiles, secondary organic aerosol production potential, and $\mathrm{OH}$ reactivity of domestic fuel combustion in Delhi, India, Environ. Sci.: Atmos., https://doi.org/10.1039/D0EA00009D, online first, 2021b.

Stewart, G. J., Nelson, B. S., Acton, W. J. F., Vaughan, A. R., Farren, N. J., Hopkins, J. R., Ward, M. W., Swift, S. J., Arya, R., Mondal, A., Jangirh, R., Ahlawat, S., Yadav, L., Sharma, S. K., Yunus, S. S. M., Hewitt, C. N., Nemitz, E., Mullinger, N., Gadi, R., Sahu, L. K., Tripathi, N., Rickard, A. R., Lee, J. D., Mandal, T. K., and Hamilton, J. F.: Emissions of intermediatevolatility and semi-volatile organic compounds from domestic fuels used in Delhi, India, Atmos. Chem. Phys., 21, 2407-2426, https://doi.org/10.5194/acp-21-2407-2021, 2021c.

Stockwell, C. E., Veres, P. R., Williams, J., and Yokelson, R. J.: Characterization of biomass burning emissions from cooking fires, peat, crop residue, and other fuels with high-resolution proton-transfer-reaction time-of-flight mass spectrometry, Atmos. Chem. Phys., 15, 845-865, https://doi.org/10.5194/acp-15845-2015, 2015.

Stockwell, C. E., Christian, T. J., Goetz, J. D., Jayarathne, T., Bhave, P. V., Praveen, P. S., Adhikari, S., Maharjan, R., DeCarlo, P. F., Stone, E. A., Saikawa, E., Blake, D. R., Simpson, I. J., Yokelson, R. J., and Panday, A. K.: Nepal Ambient Monitoring and Source Testing Experiment (NAMaSTE): emissions of trace gases and light-absorbing carbon from wood and dung cooking fires, garbage and crop residue burning, brick kilns, and other sources, Atmos. Chem. Phys., 16, 11043-11081, https://doi.org/10.5194/acp-16-11043-2016, 2016.
Strollo, C. M. and Ziemann, P. J.: Products and mechanism of secondary organic aerosol formation from the reaction of 3-methylfuran with $\mathrm{OH}$ radicals in the presence of $\mathrm{NO}_{x}$, Atmos. Environ., 77, 534-543, https://doi.org/10.1016/j.atmosenv.2013.05.033, 2013.

Taipale, R., Ruuskanen, T. M., Rinne, J., Kajos, M. K., Hakola, H., Pohja, T., and Kulmala, M.: Technical Note: Quantitative long-term measurements of VOC concentrations by PTR-MS - measurement, calibration, and volume mixing ratio calculation methods, Atmos. Chem. Phys., 8, 6681-6698, https://doi.org/10.5194/acp-8-6681-2008, 2008.

Tapia, A., Villanueva, F., Salgado, M. S., Cabañas, B., Martínez, E., and Martín, P.: Atmospheric degradation of 3-methylfuran: kinetic and products study, Atmos. Chem. Phys., 11, 3227-3241, https://doi.org/10.5194/acp-11-3227-2011, 2011.

Venkataraman, C. and Rao, G. U. M.: Emission Factors of Carbon Monoxide and Size-Resolved Aerosols from Biofuel Combustion, Environ. Sci. Technol., 35, 2100-2107, https://doi.org/10.1021/es001603d, 2001.

Venkataraman, C., Negi, G., Brata Sardar, S., and Rastogi, R.: Size distributions of polycyclic aromatic hydrocarbons in aerosol emissions from biofuel combustion, J. Aerosol Sci., 33, 503-518, https://doi.org/10.1016/S0021-8502(01)00185-9, 2002.

Venkataraman, C., Sagar, A. D., Habib, G., Lam, N., and Smith, K. R.: The Indian National Initiative for Advanced Biomass Cookstoves: The benefits of clean combustion, Energy Sustain. Dev., 14, 63-72, https://doi.org/10.1016/j.esd.2010.04.005, 2010.

Villanueva, F., Barnes, I., Monedero, E., Salgado, S., Gómez, M. V., and Martin, P.: Primary product distribution from the Cl-atom initiated atmospheric degradation of furan: Environmental implications, Atmos. Environ., 41, 8796-8810, https://doi.org/10.1016/j.atmosenv.2007.07.053, 2007.

Wang, H. L., Lou, S. R., Huang, C., Qiao, L. P., Tang, X. B., Chen, C. H., Zeng, L. M., Wang, Q., Zhou, M., Lu, S. H., and Yu, X. N.: Source Profiles of Volatile Organic Compounds from Biomass Burning in Yangtze River Delta, China, Aerosol Air Qual. Res., 14, 818-828, https://doi.org/10.4209/aaqr.2013.05.0174, 2014.

Wang, S., Newland, M. J., Deng, W., Rickard, A. R., Hamilton, J. F., Muñoz, A., Ródenas, M., Vázquez, M. M., Wang, L., and Wang, X.: Aromatic Photo-oxidation, A New Source of Atmospheric Acidity, Environ. Sci. Technol., 54, 7798-7806, https://doi.org/10.1021/acs.est.0c00526, 2020.

Warneke, C., Roberts, J. M., Veres, P., Gilman, J., Kuster, W. C., Burling, I., Yokelson, R., and de Gouw, J. A.: VOC identification and inter-comparison from laboratory biomass burning using PTR-MS and PIT-MS, Int. J. Mass Spectrom., 303, 6-14, https://doi.org/10.1016/j.ijms.2010.12.002, 2011.

West, S. K., Bates, M. N., Lee, J. S., Schaumberg, D. A., Lee, D. J., Adair-Rohani, H., Chen, D. F., and Araj, H.: Is Household Air Pollution a Risk Factor for Eye Disease?, Int. J. Env. Res. Pub. He., 10, 5378-5398, https://doi.org/10.3390/ijerph10115378, 2013.

World Health Organization (WHO): IARC monographs on the evaluation of carcinogenic risks to humans, World Health Organisation, Lyon, France, Internal report 14/002, 2016.

World Health Organization (WHO): Household Air Pollution and Health: https://www.who.int/news-room/fact-sheets/detail/ household-air-pollution-and-health (last access: 5 August 2020), 2018. 
Wiedinmyer, C., Akagi, S. K., Yokelson, R. J., Emmons, L. K., AlSaadi, J. A., Orlando, J. J., and Soja, A. J.: The Fire INventory from NCAR (FINN): a high resolution global model to estimate the emissions from open burning, Geosci. Model Dev., 4, 625641, https://doi.org/10.5194/gmd-4-625-2011, 2011.

Wiedinmyer, C., Yokelson, R. J., and Gullett, B. K.: Global Emissions of Trace Gases, Particulate Matter, and Hazardous Air Pollutants from Open Burning of Domestic Waste, Environ. Sci. Technol., 48, 9523-9530, https://doi.org/10.1021/es502250z, 2014.

World Bank: Tracking SDG 7: The Energy Progress Report 2020, Chapter 2: Access To Clean Fuels And Technologies For Cooking, International Bank for Reconstruction and Development, Washington DC, USA, 2020.

Wróblewski, T., Ziemczonek, L., Szerement, K., and Karwasz, G. P.: Proton affinities of simple organic compounds, Czech. J. Phys., 56, B1110-B1115, https://doi.org/10.1007/s10582-0060335-8, 2006.

Yamada, H., Inomata, S., and Tanimoto, H.: Evaporative emissions in three-day diurnal breathing loss tests on passenger cars for the Japanese market, Atmos. Environ., 107, 166-173, https://doi.org/10.1016/j.atmosenv.2015.02.032, 2015.

Yee, L. D., Kautzman, K. E., Loza, C. L., Schilling, K. A., Coggon, M. M., Chhabra, P. S., Chan, M. N., Chan, A. W. H., Hersey, S. P., Crounse, J. D., Wennberg, P. O., Flagan, R. C., and Seinfeld, J. H.: Secondary organic aerosol formation from biomass burning intermediates: phenol and methoxyphenols, Atmos. Chem. Phys., 13, 8019-8043, https://doi.org/10.5194/acp13-8019-2013, 2013.

Yevich, R. and Logan, J. A.: An assessment of biofuel use and burning of agricultural waste in the developing world, Global Biogeochem. Cy., 17, 1095, https://doi.org/10.1029/2002GB001952, 2003.
Yokelson, R. J., Burling, I. R., Urbanski, S. P., Atlas, E. L., Adachi, K., Buseck, P. R., Wiedinmyer, C., Akagi, S. K., Toohey, D. W., and Wold, C. E.: Trace gas and particle emissions from open biomass burning in Mexico, Atmos. Chem. Phys., 11, 67876808, https://doi.org/10.5194/acp-11-6787-2011, 2011.

Yokelson, R. J., Burling, I. R., Gilman, J. B., Warneke, C., Stockwell, C. E., de Gouw, J., Akagi, S. K., Urbanski, S. P., Veres, P., Roberts, J. M., Kuster, W. C., Reardon, J., Griffith, D. W. T., Johnson, T. J., Hosseini, S., Miller, J. W., Cocker III, D. R., Jung, H., and Weise, D. R.: Coupling field and laboratory measurements to estimate the emission factors of identified and unidentified trace gases for prescribed fires, Atmos. Chem. Phys., 13, 89-116, https://doi.org/10.5194/acp-13-89-2013, 2013.

Yu, F. and Luo, G.: Modeling of gaseous methylamines in the global atmosphere: impacts of oxidation and aerosol uptake, Atmos. Chem. Phys., 14, 12455-12464, https://doi.org/10.5194/acp-1412455-2014, 2014.

Yuan, B., Koss, A., Warneke, C., Gilman, J. B., Lerner, B. M., Stark, H., and de Gouw, J. A.: A high-resolution time-of-flight chemical ionization mass spectrometer utilizing hydronium ions $\left(\mathrm{H}_{3} \mathrm{O}^{+}\right.$ToF-CIMS $)$for measurements of volatile organic compounds in the atmosphere, Atmos. Meas. Tech., 9, 2735-2752, https://doi.org/10.5194/amt-9-2735-2016, 2016.

Yuan, B., Koss, A. R., Warneke, C., Coggon, M., Sekimoto, K., and de Gouw, J. A.: Proton-Transfer-Reaction Mass Spectrometry: Applications in Atmospheric Sciences, Chem. Rev., 117, 1318713229, https://doi.org/10.1021/acs.chemrev.7b00325, 2017.

Yucra, S., Tapia, V., Steenland, K., Naeher, L. P., and Gonzales, G. F.: Association Between Biofuel Exposure and Adverse Birth Outcomes at High Altitudes in Peru: A Matched Case-control Study, Int. J. Occup. Env. Heal., 17, 307-313, 2011.

Zhao, X. C. and Wang, L. M.: Atmospheric Oxidation Mechanism of Furfural Initiated by Hydroxyl Radicals, J. Phys. Chem. A, 121, 3247-3253, https://doi.org/10.1021/acs.jpca.7b00506, 2017. 